\title{
Energy Integration for 2050 - A Strategic Impact Model (2050 SIM), Version 1.0
}

October 2010

The INL is a

U.S. Department of Energy National Laboratory

operated by

Battelle Energy Alliance

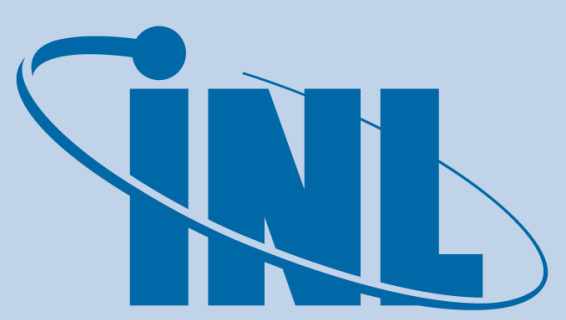

Idaho National Laboratory 


\section{DISCLAIMER}

This information was prepared as an account of work sponsored by an agency of the U.S. Government. Neither the U.S. Government nor any agency thereof, nor any of their employees, makes any warranty, expressed or implied, or assumes any legal liability or responsibility for the accuracy, completeness, or usefulness, of any information, apparatus, product, or process disclosed, or represents that its use would not infringe privately owned rights. References herein to any specific commercial product, process, or service by trade name, trade mark, manufacturer, or otherwise, does not necessarily constitute or imply its endorsement, recommendation, or favoring by the U.S. Government or any agency thereof. The views and opinions of authors expressed herein do not necessarily state or reflect those of the U.S. Government or any agency thereof. 


\section{Energy Integration for 2050 - A Strategic Impact Model (2050 SIM), Version 1.0}

October 2010

Idaho National Laboratory

Next Generation Nuclear Plant Project

Idaho Falls, Idaho 83415

Prepared for the

U.S. Department of Energy

Office of Nuclear Energy

Under DOE Idaho Operations Office

Contract DE-AC07-05ID14517 

Next Generation Nuclear Plant Project

Energy Integration for 2050 - A Strategic Impact Model (2050 SIM), Version 1.0

INL/EXT-10-19992

October 2010

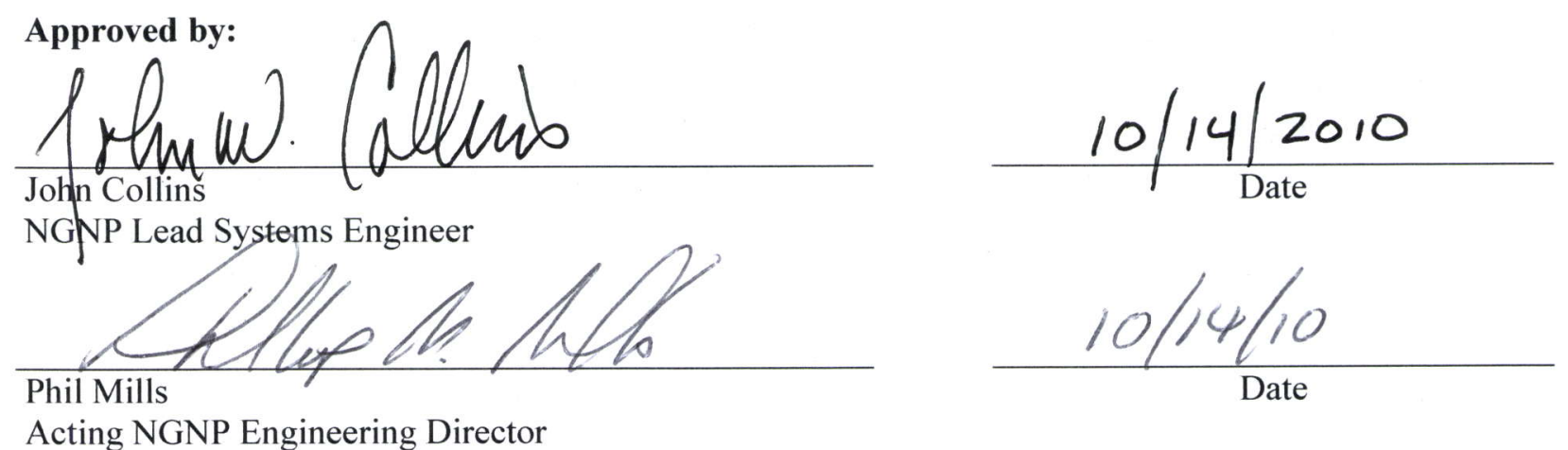





\begin{abstract}
The United States (U.S.) energy infrastructure is among the most reliable, accessible, and economical in the world. On the other hand, it is also excessively reliant on foreign energy sources, experiences high volatility in energy prices, does not always practice good stewardship of finite indigenous energy resources, and emits significant quantities of greenhouse gases (GHG). The U.S.

Department of Energy is conducting research and development on advanced nuclear reactor concepts and technologies, including High Temperature Gascooled Reactor (HTGR) technologies, directed at helping the United States meet its current and future energy challenges.

This report discusses the 2050 Strategic Impact Model (2050 SIM), Version 1.0, an initial version of which was created during the later part of FY-2010. 2050 SIM was developed to analyze and depict the benefits of various energy sources in meeting the energy demand and to provide an overall system understanding of the tradeoffs between building and using HTGRs versus other existing technologies for providing energy (heat and electricity) to various energy-use sectors in the United States. This report documents the assumptions used in the model, the rational for the model methodology, and the references for the source documentation and source data used in developing the 2050 SIM. This report also presents a sample use of the model.

It is anticipated that users will exercise the model in "what-if" analyses and determine the benefits of nuclear power, particularly HTGRs, and the significant role renewable energy (i.e., nuclear, wind, and solar) can play in transforming the U.S. energy infrastructure, reducing GHG emissions, stabilizing prices, achieving domestic energy independence, and creating jobs.
\end{abstract}

The 2050 SIM, Version 1.0, will be used by the INL development team and the results presented to interested parties. Future versions of the model will include industrial processes enhanced by the benefit of higher reactor outlet temperatures, enhanced user interface, and a user's guide. 


\section{CONTENTS}

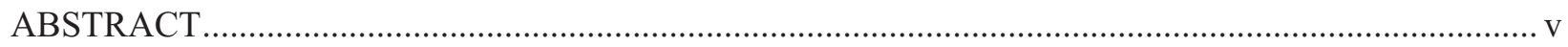

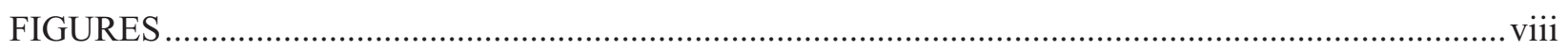

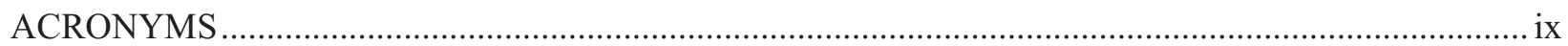

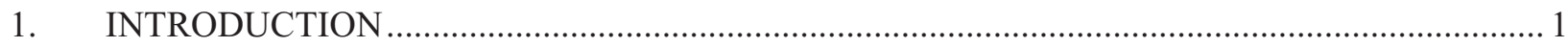

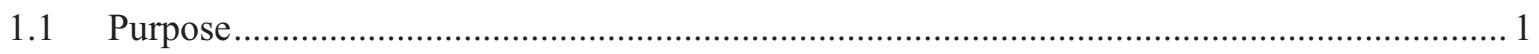

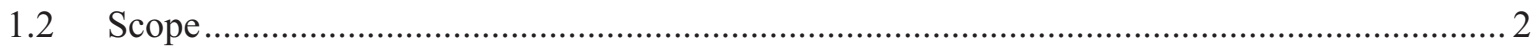

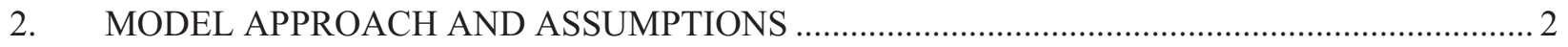

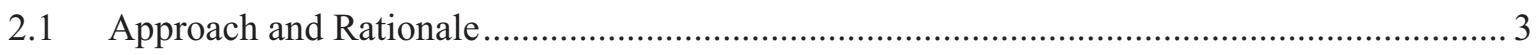

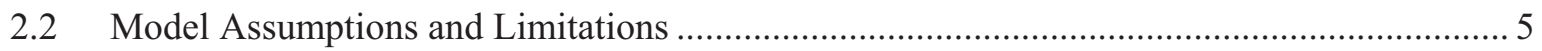

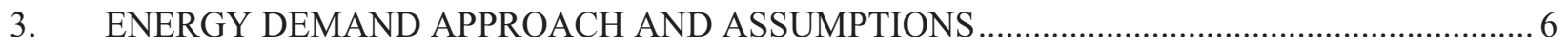

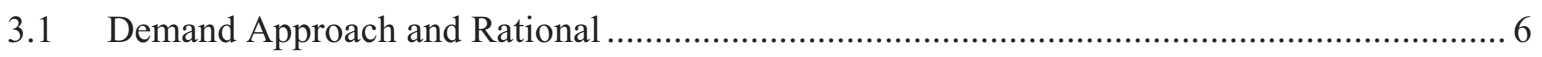

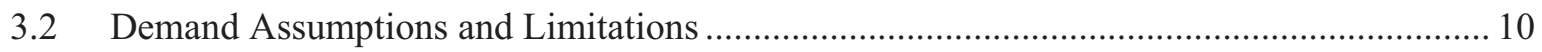

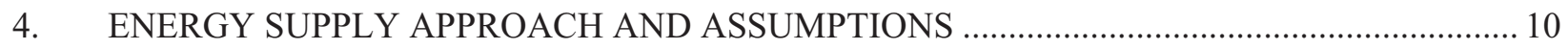

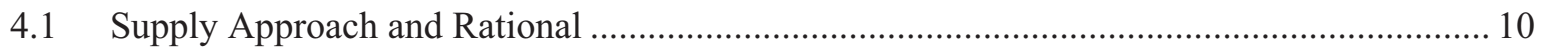

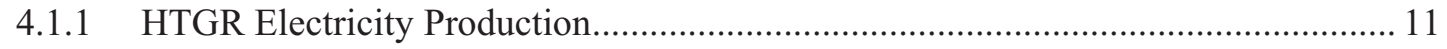

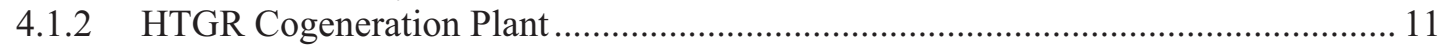

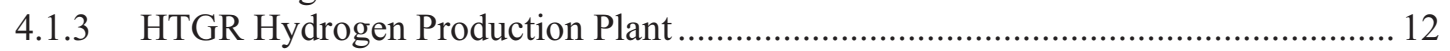

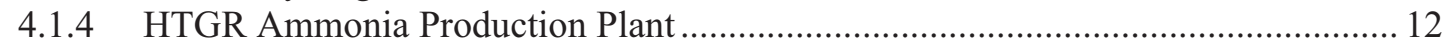

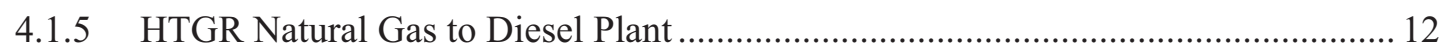

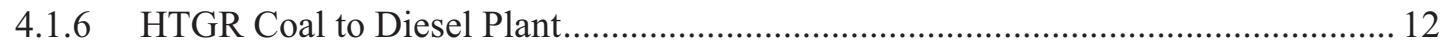

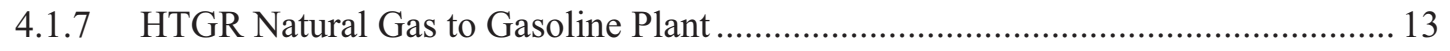

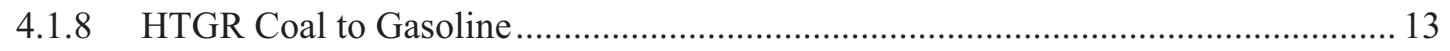

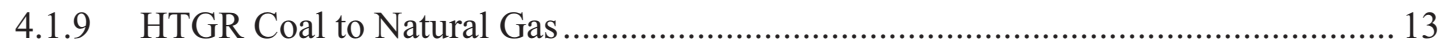

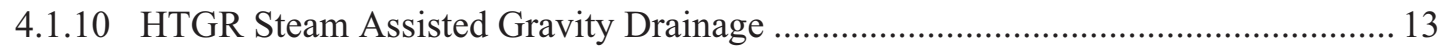

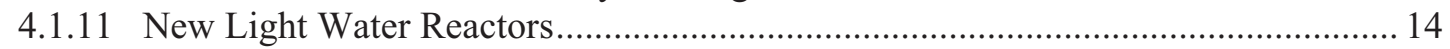

4.1.12 New Coal Integrated Gasification Combined-Cycle Plant ……................................ 14

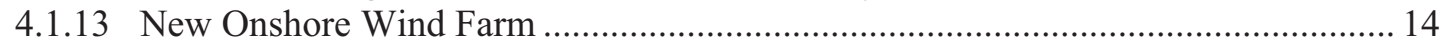

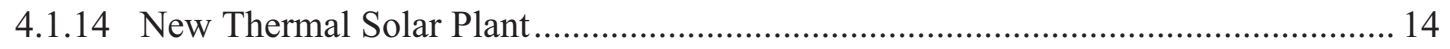

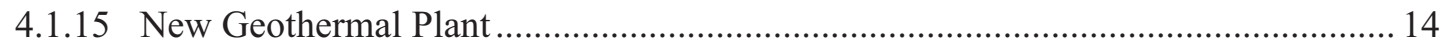

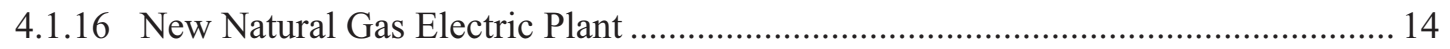

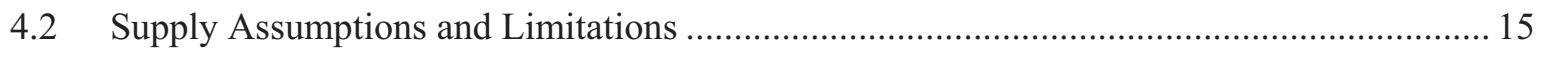

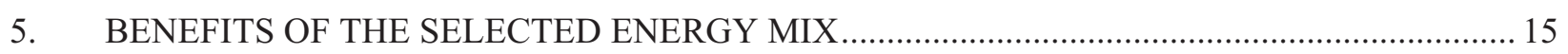

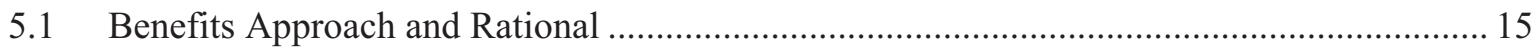

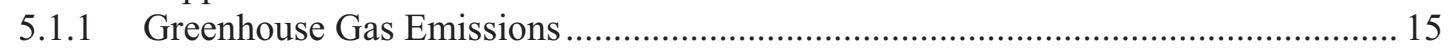

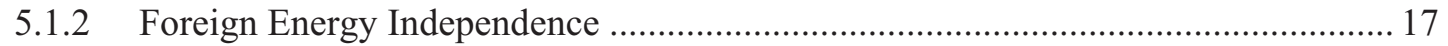

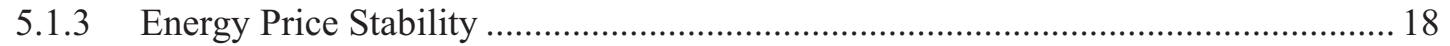

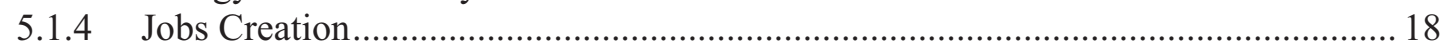

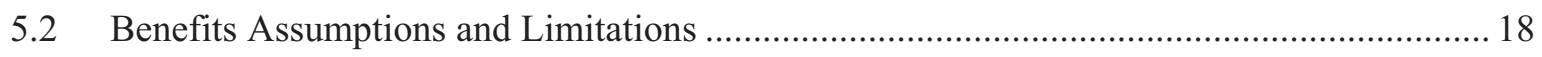

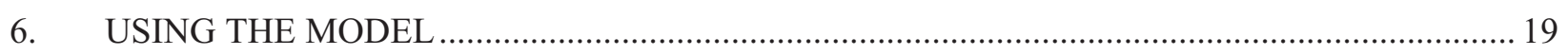

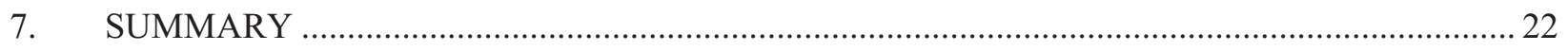

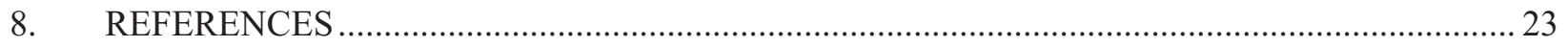




\section{FIGURES}

Figure 1. HTGRs address energy challenges while meeting energy demand ......................................... 3

Figure 2. Quantified energy consumption by source and sector ........................................................ 5

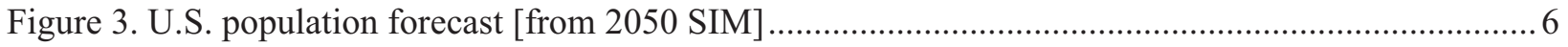

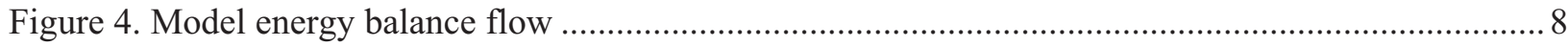

Figure 5. Historical data for number of vehicles and future estimate [from 2050 SIM] .......................... 9

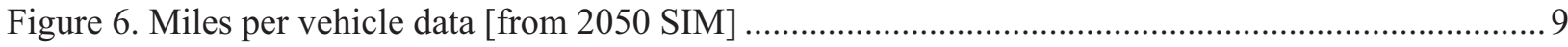

Figure 7. Historical and projected GHG emissions by source resulting only from assumed

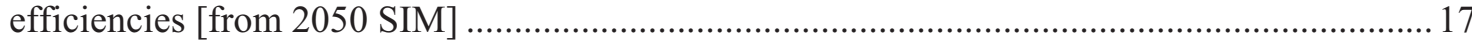

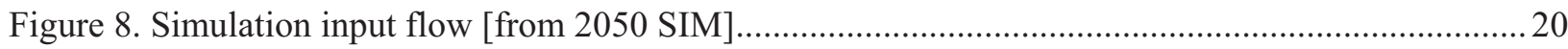

Figure 9. Future energy demand for the United States [from 2050 SIM] ...........................................21

Figure 10. Historical and projected GHG emissions by source resulting from assumed efficiencies and additional HTGRs and other nuclear and renewable energy technologies

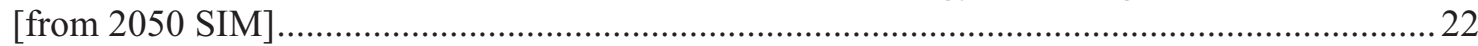

Figure 11. Job creation benefits in the United States [from 2050 SIM] ............................................22

\section{TABLES}

Table 1. Process summary

Table 2. Emissions factor summary 16 


\section{ACRONYMS}

$\begin{array}{ll}\text { BTU } & \text { British Thermal Unit } \\ \text { CAFE } & \text { corporate average fuel economy } \\ \text { CCS } & \text { carbon capture and storage } \\ \text { D\&D } & \text { decontamination and decommissioning } \\ \text { DOE } & \text { Department of Energy } \\ \text { EIA } & \text { Energy Information Administration } \\ \text { GDP } & \text { Gross Domestic Product } \\ \text { GHG } & \text { greenhouse gases } \\ \text { GUI } & \text { graphical user interface } \\ \text { HTGR } & \text { High Temperature Gas-cooled Reactor } \\ \text { HTSE } & \text { High Temperature Steam Electrolysis } \\ \text { IGCC } & \text { Integrated Gasification Combined-Cycle } \\ \text { INL } & \text { Idaho National Laboratory } \\ \text { LWR } & \text { light water reactor } \\ \text { MPG } & \text { miles per gallon } \\ \text { MWe } & \text { megawatt-electric } \\ \text { MWh } & \text { megawatt-hour } \\ \text { MWt } & \text { megawatt-thermal } \\ \text { NETL } & \text { National Energy Technology Laboratory } \\ \text { SIM } & \text { Strategic Impact Model } \\ \text { U.S. } & \text { United States }\end{array}$




\section{Energy Integration for 2050 - A Strategic Impact Model (2050 SIM)}

\section{INTRODUCTION}

The United States (U.S.) energy infrastructure is among the most reliable, accessible, and economical in the world. On the other hand, it demonstrates the following vulnerabilities: ${ }^{1}$

- Relies heavily on foreign sources of energy

- Experiences high volatility in energy prices

- Does not always practice efficient stewardship of finite indigenous energy resources

- Emits significant quantities of greenhouse gases (GHG).

To overcome U.S. energy infrastructure vulnerabilities, the nation must employ not only energy conservation and efficiency methods on the demand side but also employ new technologies on the energy supply side. Demand side conservation methods may include car pooling, work from home options, and turning off the lights and other practices. Demand side efficiency methods may include technological improvements such as increasing miles per gallon for vehicles, as well as more deploying efficient refrigerators, heating, and cooling systems. Increased use of low carbon-footprint power plants on the supply side may include deployment of contemporary nuclear power plants for electricity production and additional renewable energy sources, such as wind, solar, and geothermal power. In addition, it may include the development of new technologies, including nuclear High Temperature Gas-cooled Reactors (HTGR) for the co-production of electricity and industrial process heat, and the deployment of coal and natural gas-powered plants with carbon capture and sequestration technologies.

Nuclear reactors can play a significant role in transforming the U.S. energy infrastructure. There are currently 104 light water reactors (LWR) in the United States, which collectively supply $21 \%$ of the nation's electricity demand. ${ }^{2}$ HTGRs operate at much higher reactor outlet temperatures than conventional LWR technologies. Accordingly, HTGRs can be used in place of fossil fuels for generating heat and steam in industrial applications and for generating electric power while reducing or eliminating the GHG emissions from the power production cycle. The use of HTGR technology also provides a longterm secure energy source at a more stable price, thus insulating end users from the economic uncertainties associated with the relatively higher price volatility and uncertain availability of crude oil. HTGRs supply electricity, steam, and high-temperature gas to a wide range of industrial processes, including high temperature steam electrolysis (HTSE), which produces hydrogen and oxygen for use in petro-chemical plants, refineries, conversion of coal to transportation fuels, chemical plants, fertilizer plants, and other uses.

\subsection{Purpose}

This report presents the 2050 Strategic Impact Model (2050 SIM), Version 1.0 as a tool to facilitate analysis of the transformation of the U.S. energy infrastructure in a way that reduces the vulnerabilities while retaining the features that make the U.S. energy infrastructure world class. Much of this work is based on analyses by L. E. Demick, as published in Transforming the U.S. Energy Infrastructure. ${ }^{1}$ The 2050 SIM allows the user to evaluate the effect that maintaining the status quo has on GHG emissions, foreign oil independence, and price volatility through 2050. In addition, the model evaluates the combined benefits of HTGR products, energy efficiency, energy conservation, and other renewable energy resources and allows the user to discover the extent to which these benefits can improve the U.S. energy posture, help overcome existing and future vulnerabilities, and meet specific U.S. energy-related goals. It is intended that the current version of 2050 SIM (Version1.0) be used primarily by the Idaho 
National Laboratory (INL) development team and the results presented to interested parties. Future versions of the model will be hardened to allow for use by other interested parties.

\subsection{Scope}

High Temperature Gas-cooled Reactors have the potential to help the nation meet strategic objectives as defined in current bills pending in Congress (e.g., The American Clean Energy and Security Act of 2009 and the Clean Energy Jobs and American Power Act of 2009). The goals of these bills include but are not limited to creating new jobs in the United States, reducing U.S. dependency on foreign fuel sources, increasing energy prices stability, and reducing GHG emissions, which contribute to global warming. The extent to which these benefits are realized was modeled in 2010 based on variable assumptions, bounding conditions, and market penetration of reactor user applications into transportation, industrial, residential, and commercial sectors. This initial modeling constitutes Phase I of the 2050 SIM effort.

Phase II of the 2050 SIM effort is intended to build upon the initial model developed in 2010 by adding the enhanced user interface and expanding the scope to include further market penetration into additional industrial processes, industrial processes enhanced by the benefit of higher reactor outlet temperatures, price stability, the addition of residential and commercial sectors, and a user's guide. Further versions will also be refined, hardened, and streamlined to allow for independent use by others familiar with the nation's energy supply processes and demand sectors.

\section{MODEL APPROACH AND ASSUMPTIONS}

The 2050 SIM allows users to simulate the deployment of various combinations of energy processes to achieve specific energy goals. The model is a relatively simple but robust tool for analyzing U.S. energy supplies and demands to estimate the potential contributions that can be made by developing and deploying HTGR technologies. The general approach utilized in this project, as outlined in Figure 1, overlays renewable and HTGR energy solutions on existing energy supply sources to better meet demand sector needs and address the challenges presented. 


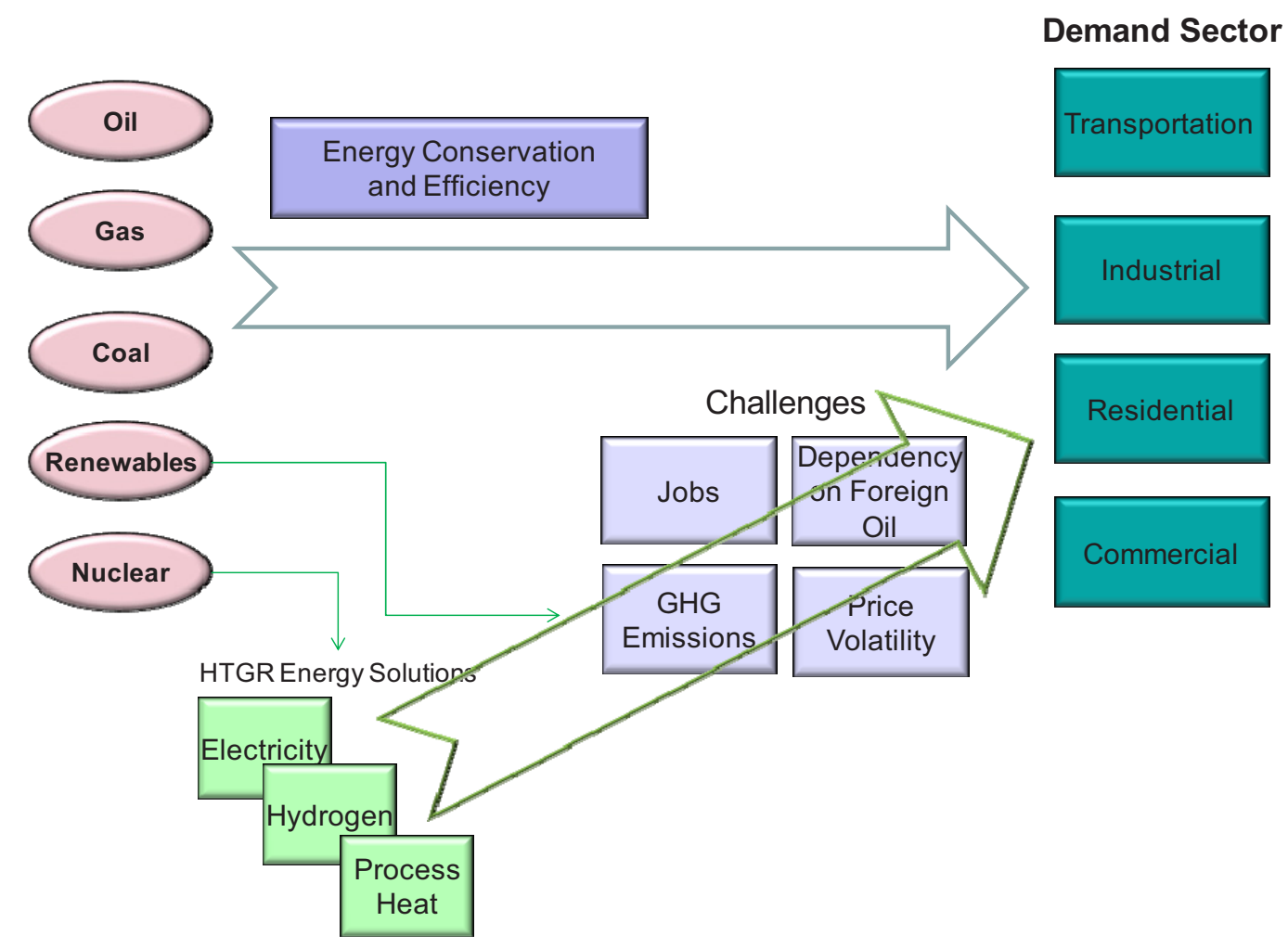

Figure 1. HTGRs address energy challenges while meeting energy demand

\subsection{Approach and Rationale}

The initial model was developed using Excel spreadsheets to allow ease of use and accessibility by the broadest range of users. Energy supply, demand, conservation, and efficiency data were collected from HTGR sources, U.S. Government documents, and other published sources. For HTGR process applications, the data used comes from the report Integration of High Temperature Gas-Cooled Reactors into Industrial Process Applications ${ }^{3}$, which discuss the following process applications:

- Ammonia Production

- Methanol-To-Gasoline Production

- Substitute Natural Gas Production

- Coal and Gas To Liquids Production

- Power Cycles for the Generation of Electricity

- Hydrogen Production

- Oil Sands Recovery via Steam-Assisted Gravity Drainage.

Detailed flowsheets were developed, and the associated technical evaluations summarize process variations, emissions, relative product costs, etc.

For the 2050 SIM, energy production and consumption data and projections were primarily collected from Energy Information Agency (EIA) ${ }^{2}$ publications and databases and supplemented as necessary with other published data. In addition, appropriate legislative and policy information (e.g., GHG reduction targets) was collected from appropriate government documents, such as draft and final legislation from the Library of Congress' THOMAS website ${ }^{4}$ and reports from the Congressional Research Service and 
the Government Accounting Office. By using primarily U.S. Government documents and other published sources, the quality of the data and information are known and each document is readily available to those who wish to review the source information.

For the 2050 SIM, applicable data and information were collected and assessed, aggregated, or separated as appropriate, and uploaded into the model spreadsheets. The data were normalized to common energy units to facilitate straight forward comparison and use, and then the appropriate links were made between the various supply and demand data sets. Energy supply data included HTGR program energyproduction estimates $^{3}$ (i.e., electricity, hydrogen, and process heat), EIA data ${ }^{2}$, and other published data for energy resources ${ }^{5,6,7,8}$ (e.g., fossil fuels, hydropower, LWRs, and alternative energy sources).

U.S. Census Bureau data were used to estimate population and population growth, and EIA data ${ }^{2}$ were used to develop the Gross Domestic Product (GDP) forecast. Both were extrapolated as necessary to allow for projections to 2050. The model initially breaks down the U.S. energy infrastructure into supply sources and demand sectors, as shown in Figure 2 (from EIA ${ }^{2}$ ). HTGR products and energy efficiency/conservation benefits were assessed against current and projected future energy demands by sector to estimate the potential for HTGR products to displace fossil fuels currently being used in each sector. For example, process heat and hydrogen from an HTGR could be used (1) to produce synthetic gasoline and diesel as a replacement for petroleum in the transportation sector or (2) in place of natural gas in ammonia production. For example, increased mileage standards (e.g., increased corporate average fuel economy [CAFE] standards) would reduce the amount of petroleum used in the transportation sector.

The deployment of HTGRs in the United States has the potential to help meet the four critical U.S. energy challenges, namely, depending on foreign oil, GHG emissions, price volatility, and jobs (see Figure 1). The design, construction, operation, and decontamination and decommissioning (D\&D) of HTGRs, along with the economic stimulus provided by obtaining new energy sources, will potentially create new jobs in the future. The production of electricity and hydrogen can potentially reduce our dependency on foreign oil by displacing the use of petroleum-based fuels in various vehicles (e.g., using electric vehicles); and electricity, hydrogen and process heat could displace the use of natural gas and oil for producing industrial process heat and industrial, residential, and commercial space heat (e.g., heating oil in the northeast). Hydrogen can be used in the industrial sector as feedstock (e.g., to supplement the use of natural gas in producing fertilizers and petrochemicals). Process heat can be used directly in the industrial sector, thereby displacing the current use of coal or natural gas. 


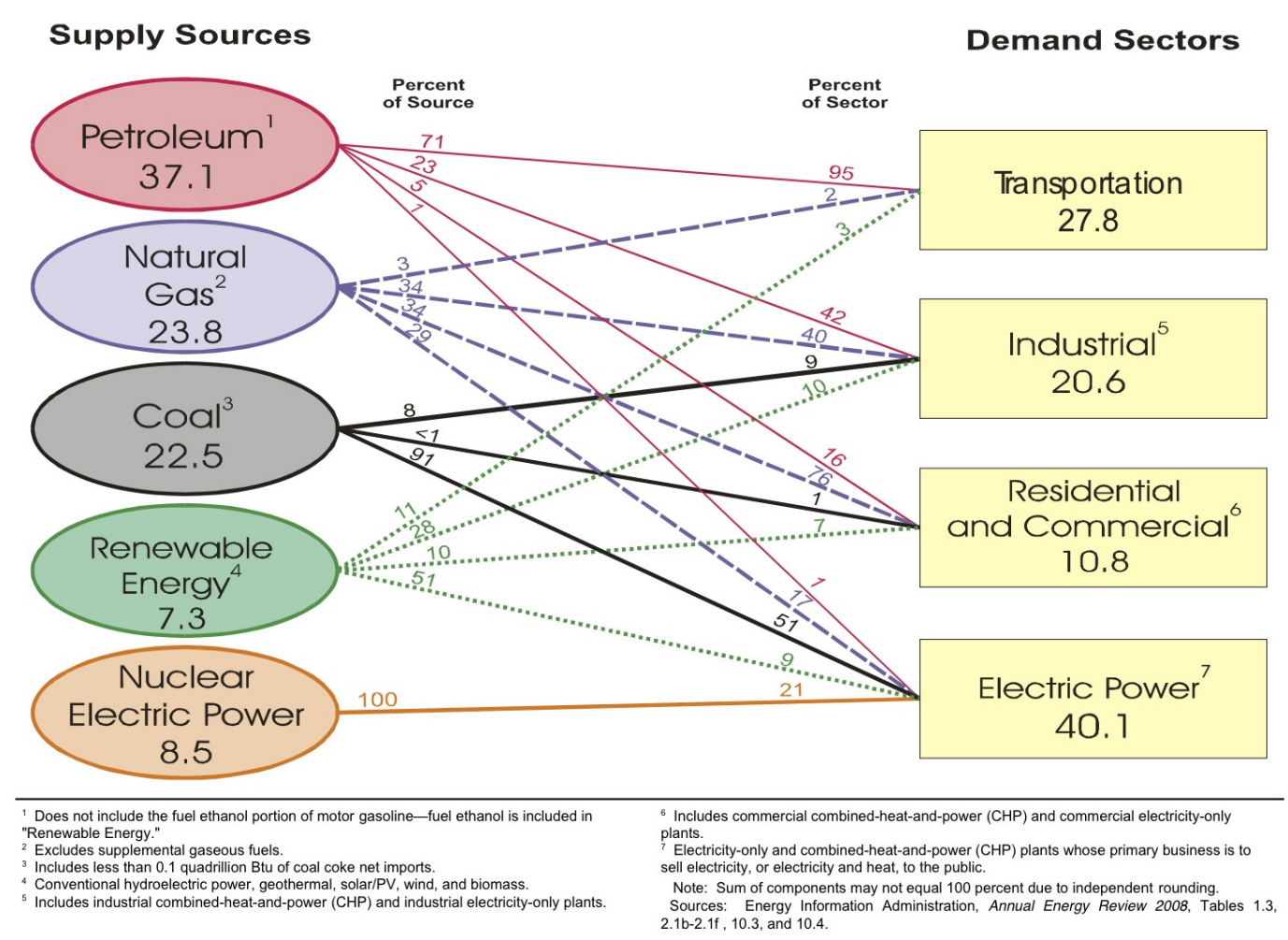

Figure 2. Quantified energy consumption by source and sector

\subsection{Model Assumptions and Limitations}

This modeling effort required data/information simplification and the use of assumptions to appropriately quantify aspects of data input and output. The general assumptions and limitations for the 2050 SIM include:

2-1. New plants/processes are built according to user specified ratios, starting in the earliest year possible, considering lead time to build (see Table 1), and then building in the next year until the user specified goals are met. If 2050 is encountered, then the model loops back to the beginning year and builds more plants stepping toward 2050 again.

2-2. New electricity producing plants (e.g., HTGRs, LWRs, renewable plants) can replace coal or natural gas fired plants according to the energy goals set by the user. No jobs lost or costs are tracked for a replaced coal or natural gas plant. If future energy demand is above 2010 levels for a particular electricity energy sector, new plants will be built to meet new demand and will not replace other energy sources, such as coal or natural gas.

2-3. The model presents energy in both metric (MWh) and English (BTU) units using accepted conversion factors.

2-4. The model uses 21,868,000 BTU/ton for an energy content for coal. This number is based on Illinois \#6 coal. ${ }^{9}$

2-5. All capital costs are in 2009 dollars, and the user is allowed to input a discount rate for the present value calculation.

2-6. For Oil Imports, the model uses past import data from $\mathrm{EIA}^{2}$ up to 2009. For future data, a $0.4 \%$ reduction per year is assumed (based on EIA ${ }^{2}$ future projections). This value could be changed to create different scenarios. 
2-7. For Natural Gas Imports, the model uses past import data from EIA ${ }^{2}$ up to 2009. For future data, a $0.6 \%$ reduction per year is assumed (based on EIA ${ }^{2}$ future projections). This value could be changed to create different scenarios.

2-8. Linear treatment of industrial process applications approximates actual process operations.

\section{ENERGY DEMAND APPROACH AND ASSUMPTIONS}

\subsection{Demand Approach and Rational}

The user initiates the 2050 SIM by selecting whether projected demand for energy will be driven by GDP or U.S. population from 2010 to 2050. If GDP is selected, then a percent change per year for GDP is used to calculate what the projected U.S. GDP will be out to 2050 . The default value is $2.4 \%$ growth per year. ${ }^{2}$ Along with GDP, the other factor needed to calculate future energy use is the energy consumption per GDP. This factor represents nation-wide energy conservation (e.g., using lights in your house less often) and efficiency (e.g., increasing vehicle mileage). The default value for this factor is a $1.9 \%$ decrease per year, based on EIA's reference case. ${ }^{2}$

If the user selects population to drive demand, a population growth rate of $0.9 \%$ per year is used (along with an energy consumption per capita factor of $-0.3 \%$ ) to estimate future energy demand out to 2050. The default values for population are found in EIA's Annual Energy Outlook 2010. ${ }^{2}$ Figure 3 shows how the population forecast using $0.9 \%$ growth fits with past population data from EIA. ${ }^{2}$

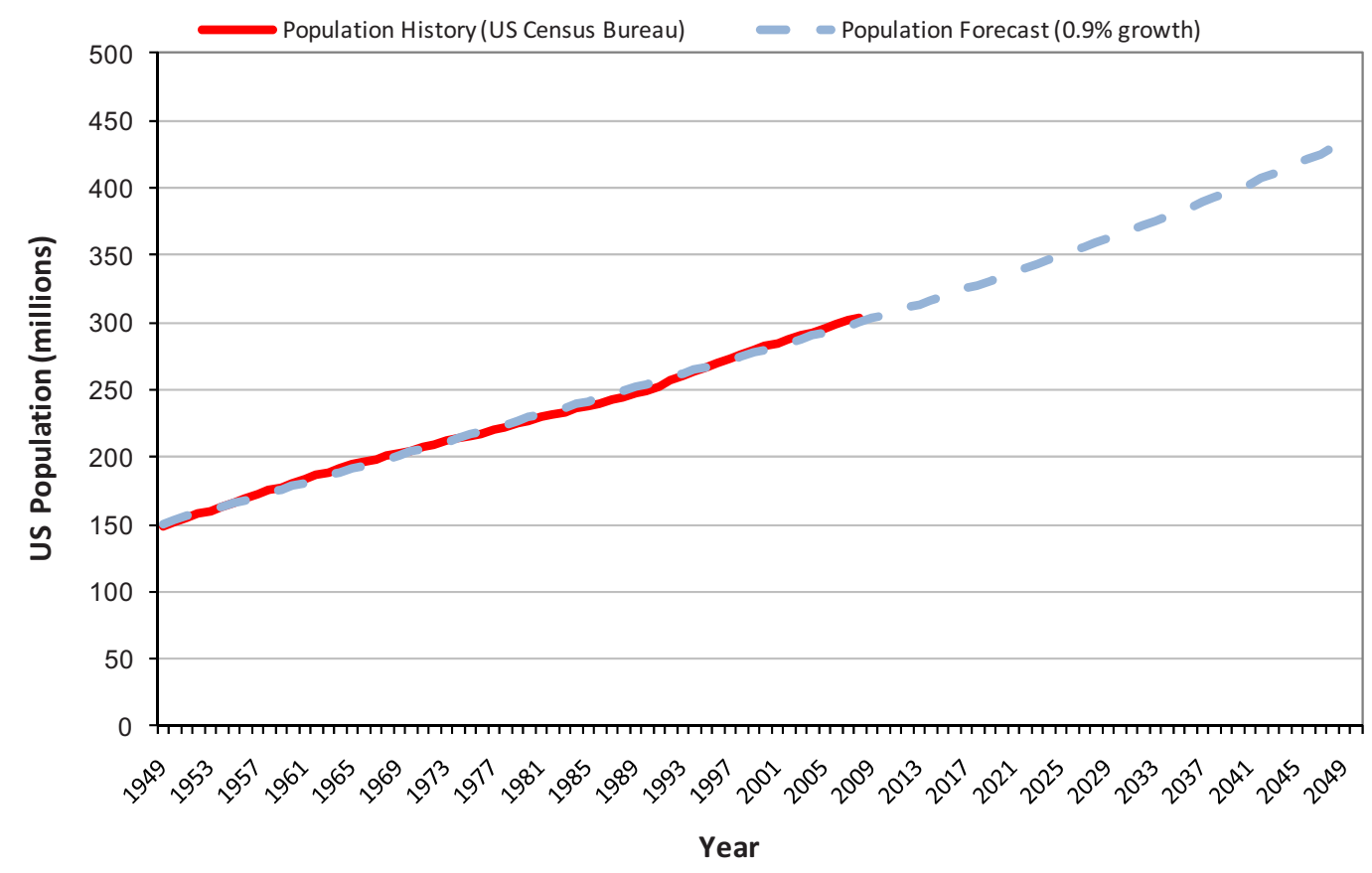

Figure 3. U.S. population forecast [from 2050 SIM]

Each of these parameters affecting future U.S. energy demand can be varied by the user to generate a range of different future energy demand scenarios.

Three user-adjustable efficiency factors are used to model the effect of energy efficiency gains in the United States. The first factor estimates efficiency in all sectors except transportation. For the transportation sector, the user predicts miles per gallon efficiency for cars and light trucks in 2020 and 2050. For the other areas of transportation (e.g., rail, heavy trucks, and air), a separate user-defined transportation efficiency factor is applied. 
Next, the total energy demand for the United States is divided into four main energy demand sectors: Transportation, Industrial, Residential \& Commercial, and Electric Power. Each demand sector is supplied by the energy source depicted in Figure 2 according to the 2008 percentage split data. As other plants/processes are built in the future, the supply source percentages change.

As new plants/processes are built to meet simulated demand, the model calculates an energy balance, as illustrated in Figure 4. This energy balance flow shows how the model simulates impacts to the four demand sectors - transportation, industrial, residential/commercial, and electricity. New energy products shown below the four energy demand sectors displace energy products shown above the demand sectors. For example, when an HTGR Hydrogen Production plant is built, it adds to the nuclear industrial supply source sector and subtracts from the natural gas industrial sector to meet the desired percentage of energy provided by each supply source. A comprehensive list of the possible plants/processes that can be built in the model are shown in Figure 4 along with their effect on the energy balance. 

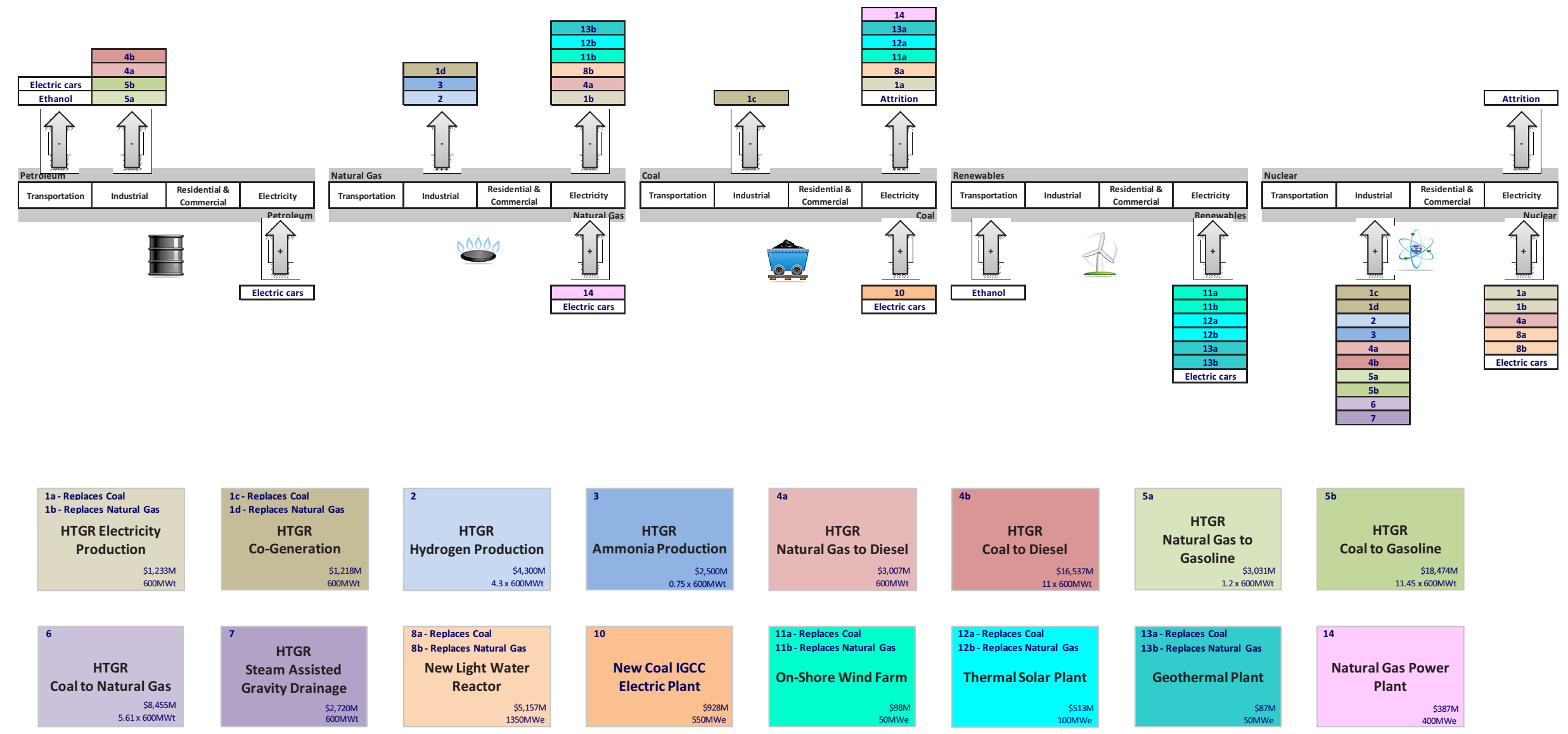

Figure 4. Model energy balance flow 
To accommodate changing miles per gallon (MPG) standards, the transportation demand sector is calculated separately for cars and light trucks. First, the number of future vehicles in use is calculated based on historical data from the Transportation Energy Data Book ${ }^{10}$, as shown in Figure 5.

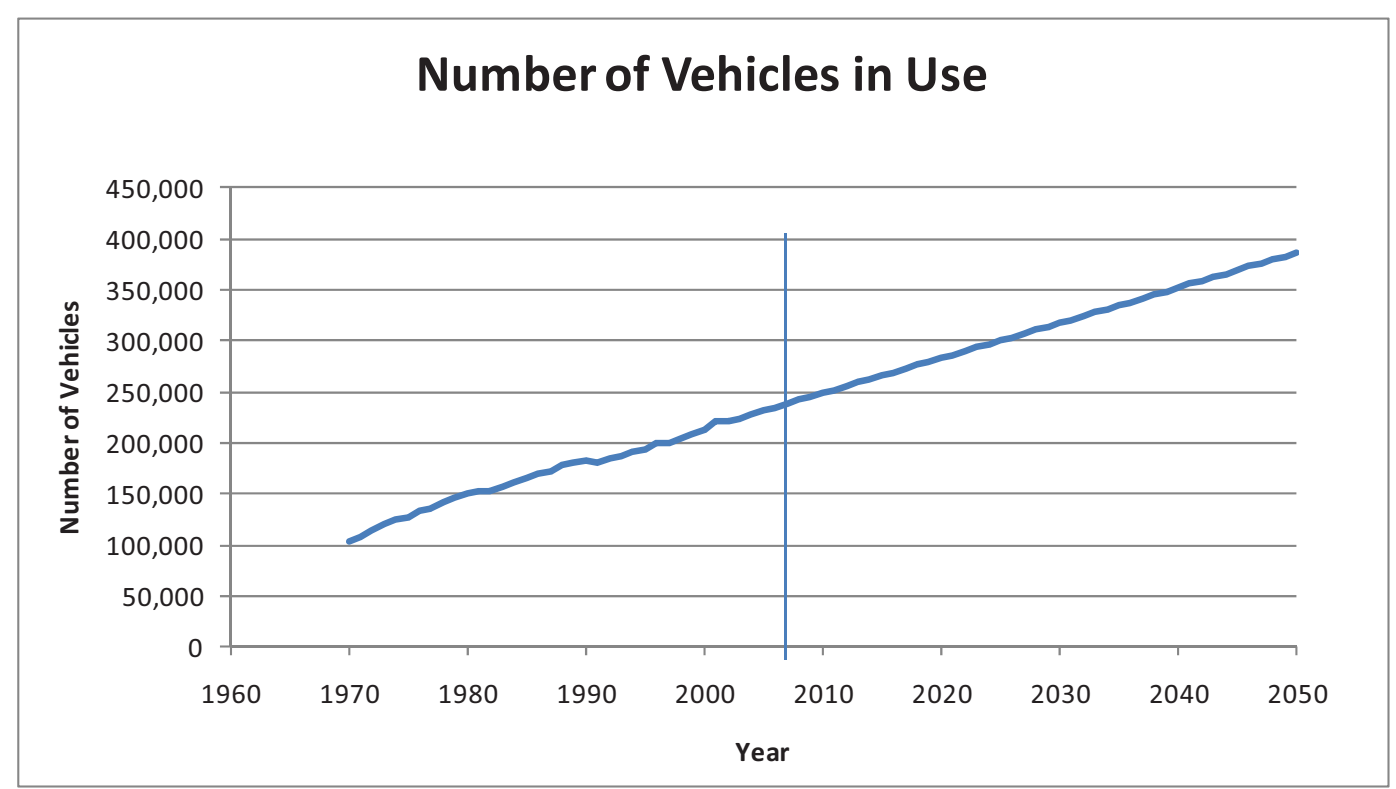

Figure 5. Historical data for number of vehicles and future estimate [from 2050 SIM]

Average U.S. MPG starts at 21 MPG for 2010 based on the current CAFE standards, and varies linearly to user inputs at 2020 and 2050. The historical data for average miles driven per vehicle was taken from the Transportation Energy Data Book ${ }^{10}$ and plotted in a graph (see Figure 6). The average has been fairly steady for the past 15 years; therefore, for the purposes of this model, it is assumed that the national average for miles per year is set at a constant 12,000 miles per year per vehicle.

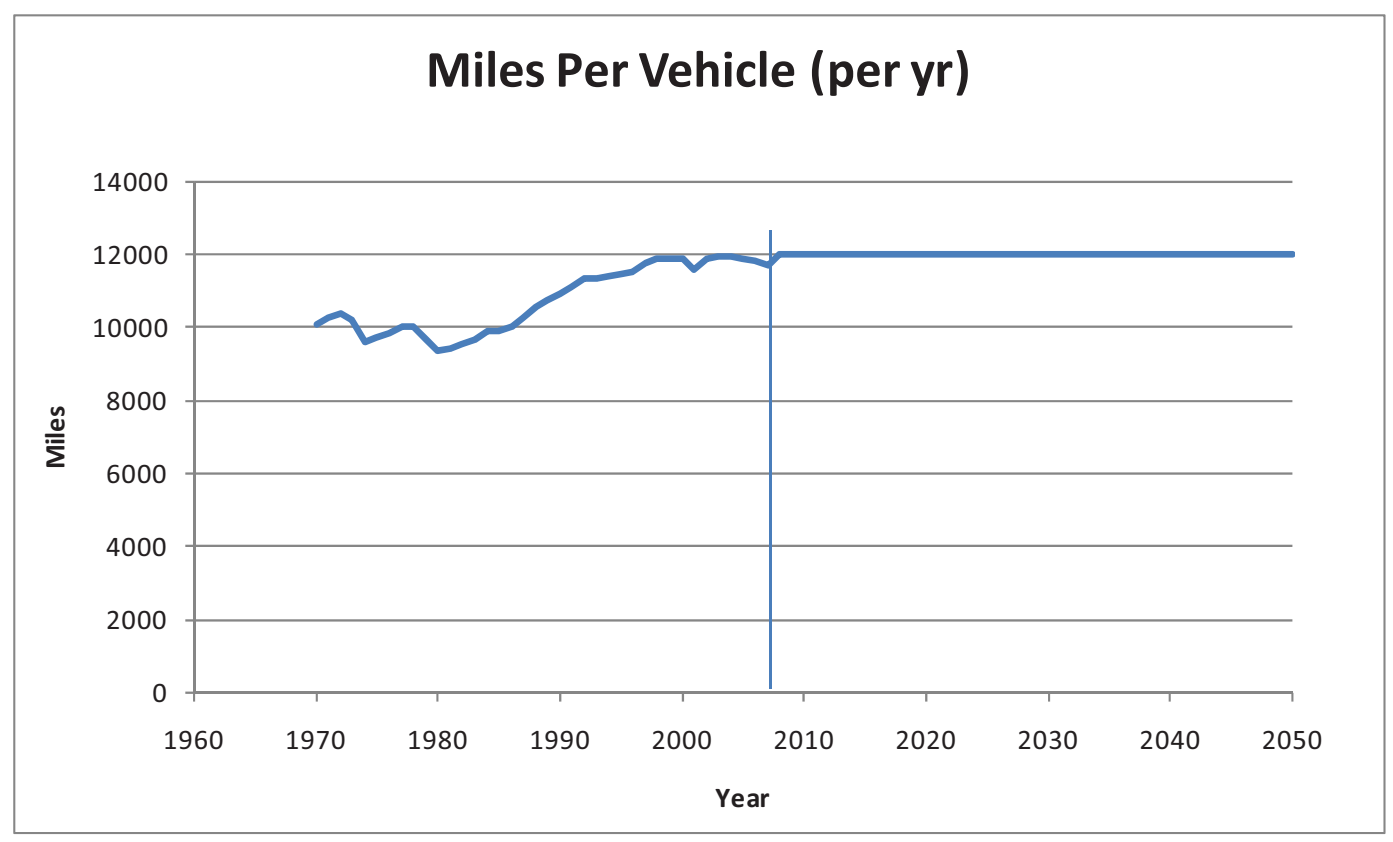

Figure 6. Miles per vehicle data [from 2050 SIM] 
Knowing the number of vehicles, miles per vehicle, and MPG, the model can then calculate national fuel use in millions of gallons per the following equation:

$$
\text { Fuel }=(\# \text { of vehicles })(\text { miles } / \text { vehicle }) /(\text { miles/gallon })
$$

Using an MPG of 21 as a baseline for 2010, the model then calculates the energy saved as MPG increases and adds it to the overall efficiency improvement explained at the beginning of this section.

\subsection{Demand Assumptions and Limitations}

The assumptions used for the demand side of the model are as follows:

\section{Energy Demand}

3-1. The model assumes the energy demand for the United States is met.

3-2. U.S. energy demand can be adjusted by the user and can be based on GDP or population.

3-3. The cost of efficiency improvements is not included in the model.

3-4. Efficiency is accounted for in the model with the efficiency factor and future MPG. Conservation is accounted for with energy use per GDP or energy use per capita.

\section{Transportation Demand}

3-5. Cost for electric cars is assumed to be absorbed by consumers and is not included in the total cost.

3-6. Transportation data used for cars and light trucks includes number of registrations (to get number of vehicles currently in use), vehicle miles traveled per year, fuel use, and fuel economy (MPG).

3-7. Future vehicle miles traveled is set to a constant 12,000 miles per vehicle per year (based on historical data, which has been close to 12,000 since $\sim 1995)$.

3-8. Future number of vehicles in use is based on a simple linear regression of past data, which is very linear.

3-9. Future MPG (a national average) is specified by the user for 2020 and 2050 (calculated as linear growth from 21.0 MPG in 2010 to each of the input values). ${ }^{10}$

3-10. Future electric vehicle use is a user input (\% of total cars) that is calculated as a linear growth from $0 \%$ in 2010 . As electric cars replace internal combustion engine cars, and energy supply is shifted from petroleum-transportation to electricity.

3-11. Ethanol use, as a percent per year, can be specified by the user for years 2022 and 2050.

3-12. Ethanol replaces gasoline use (based on the energy difference in fuels: 121,041 BTU/gal for gas $^{11}$ and 84,041 BTU/gal for ethanol ${ }^{12}$ ).

\section{ENERGY SUPPLY APPROACH AND ASSUMPTIONS 4.1 Supply Approach and Rational}

The 2050 SIM is built to supply energy to meet projected U.S. energy demand (as estimated in Section 3) according to user specified inputs. As shown in Figure 4, the 2050 SIM user can use 16 different plants/processes to affect the overall U.S. energy mix. A summary of characteristics of each plant/process is shown in Table 1. 
Table 1. Process summary (references for each line of data are shown in the "name" column)

\begin{tabular}{|c|c|c|c|c|c|c|}
\hline ID & Name & Size & $\begin{array}{l}\text { Capacity } \\
\text { Factor }\end{array}$ & $\begin{array}{l}\text { Lead } \\
\text { Time } \\
\text { (yrs) }\end{array}$ & $\begin{array}{c}\text { Plant } \\
\text { Life } \\
\text { (yrs) }\end{array}$ & $\begin{array}{c}\text { Unit cap } \\
\text { cost } \\
\text { (millions\$) }\end{array}$ \\
\hline $1 \mathrm{a}, 1 \mathrm{~b}$ & HTGR Electricity Production $^{3+}$ & $600 \mathrm{MWt}$ & $90 \%$ & 6 & 60 & 1,233 \\
\hline $1 \mathrm{c}, 1 \mathrm{~d}$ & HTGR cogeneration plant ${ }^{3+}$ & $600 \mathrm{MWt}$ & $90 \%$ & 6 & 60 & 1,218 \\
\hline 2 & HTGR Hydrogen production ${ }^{3+}$ & $4.3 \times 600 \mathrm{MWt}$ & $90 \%$ & 6 & 40 & 5,624 \\
\hline 3 & HTGR Ammonia Production ${ }^{3+}$ & $0.75 \times 600 \mathrm{MWt}$ & $90 \%$ & 6 & 40 & 2,533 \\
\hline $4 a$ & HTGR NG to Liquids ${ }^{3+}$ & $600 \mathrm{MWt}$ & $90 \%$ & 6 & 40 & 3,007 \\
\hline $4 \mathrm{~b}$ & HTGR Coal to Liquids ${ }^{3+}$ & $11 \times 600 \mathrm{MWt}$ & $90 \%$ & 6 & 40 & 16,537 \\
\hline $5 \mathrm{a}$ & HTGR NG to Gasoline ${ }^{3+}$ & $1.2 \times 600 \mathrm{MWt}$ & $90 \%$ & 6 & 40 & 3,031 \\
\hline $5 b$ & HTGR Coal to Gasoline ${ }^{3+}$ & $11.45 \times 600 \mathrm{MWt}$ & $90 \%$ & 6 & 40 & 18,474 \\
\hline 6 & HTGR Coal to $\mathrm{NG}^{3+}$ & $5.61 \times 600 \mathrm{MWt}$ & $90 \%$ & 6 & 40 & 8,455 \\
\hline 7 & HTGR SAGD $^{3+}$ & $600 \mathrm{MWt}$ & $90 \%$ & 6 & 40 & 2,720 \\
\hline 8 & New LWRs ${ }^{13}$ & 1350MWe & $90 \%$ & 6 & 60 & 5,157 \\
\hline 10 & $\begin{array}{l}\text { New Coal IGCC plant with } \\
\text { CCS }^{6,7}\end{array}$ & $550 \mathrm{MWe}$ & $80.0 \%$ & 4 & 50 & $1,328^{*}$ \\
\hline 11 & New Onshore Wind farm ${ }^{13}$ & $50 \mathrm{MWe}$ & $37.3 \%$ & 3 & 20 & 98 \\
\hline 12 & New Thermal Solar Plant ${ }^{13}$ & $100 \mathrm{MWe}$ & $37.3 \%$ & 3 & 30 & 513 \\
\hline 13 & New Geothermal Plant ${ }^{13}$ & $50 \mathrm{MWe}$ & $84 \%$ & 4 & 30 & 87 \\
\hline 14 & New Natural Gas Electric Plant ${ }^{13}$ & $400 \mathrm{MWe}$ & $87 \%$ & 3 & 50 & 387 \\
\hline
\end{tabular}

* \$1,328 for Coal IGCC plant with $90 \%$ CCS; $\$ 1,293$ for plant with $70 \%$ CCS; $\$ 1,209$ for plant with $50 \%$ CCS; $\$ 1,140$ for plant with 30\% CCS; and $\$ 928$ for plant with no CCS.

+ HTGR capacity factors are an initial assumption and will be updated as better information becomes available.

The current U.S. nuclear power reactor fleet includes 104 reactors providing about $21 \%$ of the total U.S. electricity needs. EIA ${ }^{2}$ provides information about each of these reactors and when their licenses expire. ${ }^{5}$ The model calculates when these reactors would go offline (with and without license extensions) and allows the user to specify whether or not to maintain the existing capacity by building new LWRs to replace the lost capacity out to 2050 . The model also performs the same calculation for coal fired electric plants and builds replacement capacity as needed (also using EIA data ${ }^{13}$ ). A general overview of each process is presented below, with most of the data extracted from Integration of High Temperature GasCooled Reactors into Industrial Process Applications (May 2010). ${ }^{3}$

\subsubsection{HTGR Electricity Production}

The HTGR electricity production process uses a 600MWt HTGR-integrated combined Brayton/Rankine power cycle to produce $274 \mathrm{MW}$ of electricity with a thermal efficiency of $45.7 \%$. This power cycle capitalizes on the heat production capabilities of the Brayton helium gas cycle and the $550^{\circ} \mathrm{C}$ steam requirement of the HTGR-integrated Rankine steam cycle by using the leftover heat from the Brayton cycle in the Rankine cycle so it can be converted to electricity. An added benefit is that the proportions of heat and electricity produced could be adjusted according to need.

This process adds to the nuclear electricity sector and can subtract from the coal electricity or natural gas electricity sector depending on which type of plant it replaces, or it can be a new process to meet increased demand.

\subsubsection{HTGR Cogeneration Plant}

In the HTGR cogeneration power cycle, high-pressure helium, also called "working gas," is expanded in a turbine to produce power. The low-pressure warm gas is cooled in an ambient cooler, which reduces 
the compression power, and the low-pressure cold gas is compressed to the system's high pressure. The reactor heat is separated from the power cycle by two circulation loops: the primary helium loop and the secondary helium loop. This power cycle uses $600 \mathrm{MWt}$ to produce $92 \mathrm{MWe}$ and $416 \mathrm{MWt}$ of hightemperature process heat at temperatures in excess of $600^{\circ} \mathrm{C}$, which makes it ideal for applications that require a combination of power and heat. The overall thermal efficiency of this cycle is $47.6 \%$ for the power generation portion of the process.

This process adds to the nuclear industrial sector and subtracts from the coal industrial or natural gas industrial sector depending on which type of plant it replaces.

\subsubsection{HTGR Hydrogen Production Plant}

Hydrogen is a key element required in the production of many chemical and industrial products, such as ammonia and synthetic hydrocarbon fuels. A conventional method for generating hydrogen is the steam methane reforming process, which converts steam and methane into carbon monoxide and hydrogen. This method uses natural gas as a source of energy and generates significant GHG emissions.

An HTGR-integrated process model was developed based on the production capacity of a typical conventional steam reformer, approximately 700 tons/day hydrogen. The model incorporates HTSE and uses electrical power to split water into hydrogen and oxygen. The model assumes a Rankine power cycle efficiency of $40 \%$. Each HTGR-integrated plant uses 2,580 MWt of reactor generated heat $(4.3 \times$ 600MWt HTGRs).

This process replaces natural gas steam reforming and therefore adds to the nuclear industrial sector and subtracts from the natural gas industrial sector. Because it replaces natural gas steam reforming, it reduces natural gas use by 98 million cubic feet per day (per plant).

\subsubsection{HTGR Ammonia Production Plant}

The unit operations for HTGR ammonia production are the same as the conventional (natural gas to ammonia) case with the following exceptions: (1) the HTGR provides some of the heat for hydrogen generation in the primary reformer, and (2) nuclear heat is used to preheat all streams entering the primary reformer. This case requires the energy output of $450 \mathrm{MWt}(0.75 \times 600 \mathrm{MWt}$ HTGRs $)$.

This process replaces natural gas steam reforming and therefore adds to the nuclear industrial sector and subtracts from the natural gas industrial sector. Because it replaces natural gas steam reforming, it reduces natural gas use by 16 million cubic feet per day (per plant).

\subsubsection{HTGR Natural Gas to Diesel Plant}

The analysis of the conventional natural gas-based case indicated that an HTGR could supply the "preheat" for several of the unit operations normally supplied by burning natural gas or light gas from the process. As a result, some of the natural gas combustion requirement would be avoided, reducing GHG emissions. The HTGR case requires the energy output of one $600 \mathrm{MWt}$ HTGR to equal the production of the conventional case.

This process also creates a surplus of $112.9 \mathrm{MWe}$, which adds to the nuclear electricity sector and subtracts from the natural gas electricity sector. It also uses 392 million cubic feet of natural gas per day (per plant), which increases natural gas use. This process also adds to the nuclear industrial sector and subtracts from the petroleum industrial sector (replacing diesel refining), and produces 4,340 tons per day of $\mathrm{CO}_{2}$ emissions.

\subsubsection{HTGR Coal to Diesel Plant}

Analysis of coal to diesel processes showed an opportunity for HTSE, which could provide hydrogen and oxygen while reducing coal requirements and subsequent GHG emissions. In the conventional process, only one-third of the carbon in the coal ends up in the final product as compared to over $98 \%$ in 
the HTGR-integrated case. The HTGR case requires the energy output of eleven 600 MWt HTGRs to equal the production of the conventional case.

This process uses 9,520 tons of coal per day (per plant), which increases coal use. This process also adds to the nuclear industrial sector and subtracts from the petroleum industrial sector (replacing diesel refining), and produces 1,874 tons per day of $\mathrm{CO}_{2}$ emissions.

\subsubsection{HTGR Natural Gas to Gasoline Plant}

The unit operations for the natural gas to gasoline case are the same as the conventional case with the following exceptions: (1) the HTGR provides some of the heat for the primary reformer, and (2) nuclear heat is used to preheat all streams entering the primary reformer and to fire fuel gas for product upgrading in the methanol-to-gasoline plant. The process would generate less $\mathrm{CO}_{2}$ emissions than the conventional process. The HTGR-integrated case was calculated to require the output equivalent of $720 \mathrm{MWt}(1.2 \times$ $600 \mathrm{MWt}$ HTGRs) to equate production with the conventional case.

This process uses 258 million cubic feet of natural gas per day (per plant), which increases natural gas use in the United States (since the conventional process is not currently being performed in the United States). This process also adds to the nuclear industrial sector and subtracts from the petroleum industrial sector (replacing gasoline refining), and produces 884 tons per day of $\mathrm{CO}_{2}$ emissions.

\subsubsection{HTGR Coal to Gasoline}

The unit operations for the coal to gasoline case are the same as the conventional case except that the HTSE provides 1,939 tons per day of hydrogen for the process, which replaces the need for the cryogenic air separation unit and water gas shift reactors. Because an HTGR-integrated process requires $54 \%$ less coal, the carbon fraction in the coal partitioned to the liquid fuel products would increase from $45 \%$ to $98 \%$, an improvement in carbon utilization. The process would therefore generate less $\mathrm{CO}_{2}$ emissions than the conventional process. Even if the conventional process includes carbon capture and storage (CCS), the HTGR-integrated process would generate less $\mathrm{CO}_{2}$ emissions. The HTGR-integrated process would also produce 6,941 tons per day of oxygen, which could be sold or redirected to another process. The HTGRintegrated case was calculated to require the energy output of $6,870 \mathrm{MWt}(11.45 \times 600 \mathrm{MWt}$ HTGRs $)$ to equate production with the conventional case.

This process uses 11,845 tons of coal per day (per plant), which increases coal use. This process also adds to the nuclear industrial sector and subtracts from the petroleum industrial sector (replacing gasoline refining), and produces 481 tons per day of $\mathrm{CO}_{2}$ emissions.

\subsubsection{HTGR Coal to Natural Gas}

Based on the analysis, an HTGR-integrated coal to natural gas case was developed. The HTGRintegrated case still produces GHG emissions because it uses topping heat. The HTGR-integrated process would produce 4,898 tons per day oxygen that could be sold or redirected to another process. However, due to the lack of demand for large volumes of oxygen, the revenue from the sale of $\mathrm{O}_{2}$ was not included in the economic evaluation. This case requires the energy output of 3,428 MWt $(5.61 \times 600 \mathrm{MWt}$ HTGRs) to equal the production of the conventional case.

This process uses 3,864 tons of coal per day (per plant), which increases coal use while producing 148 million cubic feet of natural gas per day (per plant). This process also adds to the nuclear industrial sector. It also produces 383 tons per day of $\mathrm{CO}_{2}$ emissions.

\subsubsection{HTGR Steam Assisted Gravity Drainage}

The HTGR-integrated model for steam assisted gravity drainage was developed based on identified opportunities for heat integration. The analysis of the conventional case showed an opportunity to generate steam with nuclear heat as opposed to heat derived from natural gas. As a result, HTGR integration eliminates nearly all GHG emissions. The unit operations for the HTGR-integrated case are 
the same as for the conventional case, except the HTGR is used to generate steam. Electricity for the HTGR-integrated process was assumed to be imported from the electrical grid. This case requires the energy output of one $600 \mathrm{MWt}$ HTGR to equal the production of the conventional case.

This process adds to the nuclear industrial sector but does not subtract from the natural gas industrial sector since it is not currently being used in the United States. If this process is built and used in the United States, it offsets crude oil imports (50,000 barrels per day, per plant).

\subsubsection{New Light Water Reactors}

The model can evaluate the deployment of new advanced LWRs based on data from EIA. ${ }^{13}$ Each new plant is assumed to produce 1,350 MWe with a capacity factor of $90 \%$. The data from the existing LWR fleet is used and the user can choose to extend licenses (for 20 years) on reactors that have not already received license extensions. The user can also choose to build LWR plants to replace LWR plants that are being retired in the future. In addition, new LWRs can be built to replace coal fired or natural gas fired electricity generating plants.

New LWRs add to the nuclear electricity sector and can subtract from the coal electricity or natural gas electricity sector, depending on which type of plant it replaces, or they can be new reactors to meet increased demand.

\subsubsection{New Coal Integrated Gasification Combined-Cycle (IGCC) Plant}

The model can evaluate the deployment of new coal Integrated Gasification Combined-cycle (IGCC) plants based on data from NETL. ${ }^{6}$ Each new plant is assumed to produce $550 \mathrm{MWe}$ with a capacity factor of $80 \%$. The user can select the amount of carbon sequestration that is used when a new plant is built. The model will automatically build new coal plants to replace plants that are being retired in the future. New coal IGCC plants add to the coal electricity sector.

\subsubsection{New Onshore Wind Farm}

The model can evaluate the deployment of new onshore wind farms based on data from EIA. ${ }^{13}$ Each new wind farm is assumed to produce 50 MWe with a capacity factor of $37.3 \%$. New wind farms can be built to replace coal fired or natural gas fired electricity generating plants. New wind farms add to the renewable electricity sector and subtract from either the natural gas electricity sector or coal electricity sector, or they can be new farms to meet increased demand.

\subsubsection{New Thermal Solar Plant}

The model can evaluate the deployment of new thermal solar plants based on data from EIA. ${ }^{13}$ Each new solar is assumed to plant produce $100 \mathrm{MWe}$ with a capacity factor of $37.3 \%$. New solar plants can be built to replace coal fired or natural gas fired electricity generating plants. New solar plants add to the renewable electricity sector and subtract from either the natural gas electricity sector or coal electricity sector, or they can be new plants to meet increased demand.

\subsubsection{New Geothermal Plant}

The model can evaluate the deployment of new geothermal plants based on data from EIA. ${ }^{13}$ Each new geothermal plant is assumed to produce $50 \mathrm{MWe}$ with a capacity factor of $84 \%$. New geothermal plants can be built to replace coal fired or natural gas fired electricity generating plants. New geothermal plants add to the renewable electricity sector and subtract from either the natural gas electricity sector or coal electricity sector, they can be new plants to meet increased demand.

\subsubsection{New Natural Gas Electric Plant}

The model can evaluate the deployment of new natural gas fired electricity production plants based on data from EIA. ${ }^{13}$ Each new natural gas electric plant is assumed to produce $400 \mathrm{MWe}$ with a capacity factor of $87 \%$. New natural gas electric plants can be built to replace coal fired electricity generating 
plants. New natural gas electric plants add to the natural gas electricity sector and subtract from the coal electricity sector, they can be new plants to meet increased demand.

\subsection{Supply Assumptions and Limitations}

The assumptions used for the supply side of the model are as follows:

4-1. If nuclear is set to " 0 ," the user unchecks license renewal and does not build any new reactors.

4-2. If nuclear is set to less than $21 \%$, the user builds enough LWRs to maintain percentage but does not build any new HTGR reactors (for electricity).

4-3. If "Maintain LWR Fleet" is checked, then the end result percentage for Nuclear will be $21 \%$ or greater.

4-4. If building HTGRs, the default start date is 2021 but can be changed by the user. If building LWRs. 2016 is the earliest date a new LWR could be practically deployed.

4-5. If building new renewables, 2014 is the earliest date a new renewable plants could be practically deployed.

4-6. The model will build new natural gas fired electric power plants if the percentage of natural gas for the electricity sector is increased.

4-7. The model will build new coal fired electric power plants (with user specified CCS) to maintain the specified percentage of coal electricity production and as the current fleet of coal plants retire (assuming a 50 year life). The choices for the number of plants that will use CCS are $0 \%, 30 \%, 50 \%$, and $90 \%$.

4-8. For process applications that produce gasoline or diesel, equivalent energy is taken out of the industrial petroleum sector (for decreased crude oil refining) based on the energy used to refine oil: $3,388,626 \mathrm{BTU} / \mathrm{bbl} .^{14}$

4-9. All new cogeneration using nuclear energy (process heat and electricity) will be used in the industrial sector.

\section{BENEFITS OF THE SELECTED ENERGY MIX 5.1 Benefits Approach and Rational}

As stated above, the 2050 SIM compares the user-selected input scenarios and their impact on four national challenges, as follows:

- GHG production

- Dependence on foreign energy sources

- Energy price stability

- Jobs creation.

Other important areas, such as stewardship of indigenous resources and pollution prevention, were considered but not explicitly quantified as a benefit, under the present scope.

\subsubsection{Greenhouse Gas Emissions}

Greenhouse gases in the atmosphere absorb and emit radiation within the thermal infrared range. This process is the fundamental cause of the greenhouse effect. The primary GHGs in the earth's atmosphere are water vapor, carbon dioxide, methane, nitrous oxide, and ozone. GHGs affect the temperature of the earth; without them, earth's surface would be on average about $33^{\circ} \mathrm{C}\left(59^{\circ} \mathrm{F}\right)$ colder than at present..$^{15}$ The 
burning of fossil fuels - including petroleum products, coal, and natural gas - contributes to the levels of $\mathrm{CO}_{2}$ in the atmosphere. Renewable energy sources - such as wind, solar, and geothermal, nuclear power and hydroelectric power - do not burn fossil fuels and therefore have a minimal carbon footprint. To compare each energy source on a common basis, none of the energy sources consider the mining operation (e.g., coal mining, uranium mining) in the GHG production equations.

The United States accounts for about one-third of all GHG emissions world-wide, and the U.S. energy sector accounts for about $84 \%$ of the U.S. GHG emissions. ${ }^{2}$ As a non- $\mathrm{CO}_{2}$ emitting substitute for the burning of fossil fuels in industrial applications, the HTGR offsets significant quantities of $\mathrm{CO}_{2}$ emissions attendant to the burning of these fuels. This includes both the direct combustion of these fuels in the industrial processes (e.g., providing steam, electricity for internal use, and high temperature gas) as well as the emissions associated with electrical power taken from the grid. This is one of the several benefits of the HTGR technology that have been explored in the 2050 SIM. Several studies have been performed that demonstrate this benefit as well as the technical and economic viability of integrating the HTGR technology with specific applications ${ }^{3}$ (e.g., cogeneration of steam, electricity and high temperature gas, coal to liquid transportation fuel conversion, bitumen extraction from oil sands using steam assisted gravity drainage, chemical production, and ammonia and ammonia derivative production).

$\mathrm{CO}_{2}$ emissions are calculated based on data from EIA. ${ }^{2}$ EIA provided both total emissions for each energy sector and total energy supplied for each sector for $2007 .^{2}$ From this, average emissions per energy factor can be calculated based on the following equation:

\section{Emissions per energy factor $=$ Total emissions/Total energy}

Table 2 summarizes the factors used in the model. The model calculates the amount of energy in each sector for each year. This energy amount is then multiplied by the emissions per energy factor to get the current year emissions.

Table 2. Emissions factor summary ${ }^{2}$

\begin{tabular}{|l|c|c|c|c|c|c|c|c|c|c|c|c|}
\hline & \multicolumn{4}{|c|}{ Petroleum } & \multicolumn{4}{c|}{ Natural Gas } & \multicolumn{4}{c|}{ Coal } \\
\hline & Transp. & Industr. & $\begin{array}{c}\text { Res \& } \\
\text { Comm. }\end{array}$ & Electric & Transp. & Indust. & $\begin{array}{c}\text { Res \& } \\
\text { Comm. }\end{array}$ & Electric & Transp. & Industr. & $\begin{array}{c}\text { Res \& } \\
\text { Comm. }\end{array}$ & Electric \\
\hline $\begin{array}{l}\text { Total } \\
\text { emissions }\end{array}$ & 1,974 & 406 & 134 & 66 & 35 & 405 & 420 & 376 & 0 & 172 & 7.4 & 1,980 \\
\hline $\begin{array}{l}\text { Total } \\
\text { Energy }^{\mathbf{b}}\end{array}$ & $27 \times 10^{6}$ & $8.7 \times 10^{6}$ & $1.8 \times 10^{6}$ & $4.1 \times 10^{5}$ & $5.7 \times 10^{5}$ & $8.4 \times 10^{6}$ & $8.4 \times 10^{6}$ & $7.0 \times 10^{6}$ & 0 & $1.9 \times 10^{6}$ & $1.1 \times 10^{5}$ & $21 \times 10^{6}$ \\
\hline $\begin{array}{l}\text { Emissions } \\
\text { per } \\
\text { Energy }^{\mathbf{c}}\end{array}$ & $7.3 \times 10^{-5}$ & $4.6 \times 10^{-5}$ & $7.6 \times 10^{-5}$ & $1.6 \times 10^{-4}$ & $6.2 \times 10^{-5}$ & $4.8 \times 10^{-5}$ & $5.0 \times 10^{-5}$ & $5.4 \times 10^{-5}$ & $\mathrm{~N} / \mathrm{A}$ & $9.1 \times 10^{-5}$ & $6.7 \times 10^{-5}$ & $9.4 \times 10^{-5}$ \\
\hline
\end{tabular}

$\mathrm{a}-$ Million Metric Tons $\mathrm{CO}_{2} \quad \mathrm{~b}$ - Billion BTUs $\quad \mathrm{c}-$ Million Metric Tons $\mathrm{CO}_{2}$ per Billion BTU

Current legislation being considered by Congress (e.g., The American Clean Energy and Security Act of 2009 and the Clean Energy Jobs and American Power Act of 2009) would require varying levels of reduction in GHG emissions by the year 2030 and extrapolated to the year 2050, some as high as an $83 \%$ reduction over 2005 emission levels. Reductions of this magnitude would penetrate all sectors and require significant transformation of the energy infrastructure. The $2050 \mathrm{SIM}$ estimates future $\mathrm{CO}_{2}$ emissions for each future energy scenario selected by the user. Figure 7 shows a sample output graph of potential GHG reductions resulting from efficiency applications within each sector without using additionaly HTGRs or other nuclear or renewable energy technologies. The upper most line indicates projected GHG emissions if no efficiencies are applied. The green area shows the approximately 1,200 million metric tons cumulative reduction in GHG emissions that could occur if assumed efficiencies are realized. Additional reductions can be achieved in each sector as energy sources are replaced with additional HTGR and other nuclear and renewable energy technologies. Potential reductions that can be realized from these technology applications are shown in Figure 10 (see Section 6). 


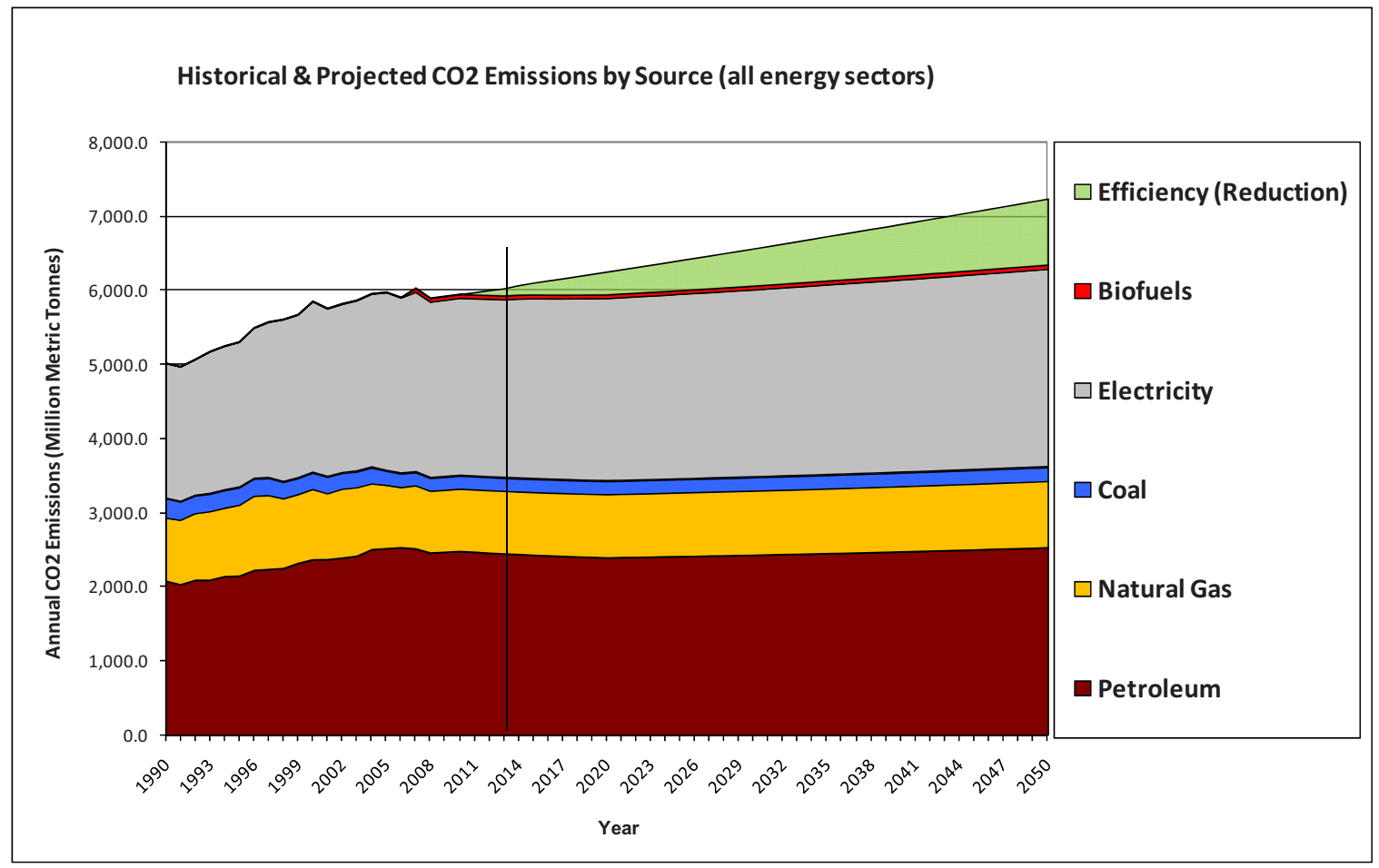

Figure 7. Historical and projected GHG emissions by source resulting only from assumed efficiencies [from 2050 SIM]

Emissions for ethanol are calculated based on the factor for petroleum transportation $\left(7.3 \times 10^{-5}\right.$ million metric tons $\mathrm{CO}_{2}$ per billion BTU) multiplied by the ratio $\left(7.4 / 7.9\right.$ or $93.7 \%$ ) because ethanol $\mathrm{CO}_{2}$ emissions are slightly less than gasoline $\mathrm{CO}_{2}$ emissions. This ratio $(93.7 \%)$ originates from an $\mathrm{EIA}^{16}$ report wherein it states that $\mathrm{CO}_{2}$ emissions from gasoline are 7.9 moles per vehicle mile travelled and emissions from ethanol are 7.4 moles per vehicle mile travelled. $\mathrm{CO}_{2}$ emissions for other renewable energy sectors and for nuclear energy are assumed to be negligible for version 1.0 of the 2050 SIM.

\subsubsection{Foreign Energy Independence}

The United States currently imports $60 \%$ of its crude oil supply from foreign sources and consumes the oil primarily in the U.S. transportation sector (95\% of car and light truck transportation use petroleum). Several of the foreign sources represent governments that are antagonist to the United States. This daily foreign acquisition represents not only an export of U.S. wealth but also a vulnerability to the U.S. economy, security ${ }^{16}$, and way of life.

The 2050 SIM depicts the extent to which foreign energy independence is attained through the use of domestic resources and domestic gasoline and diesel production technologies, and alternative energy efficiency technologies (e.g., electric and hybrid vehicles). The model depicts the reduction of crude oil importation by allowing the user to:

- Adjust the use of hybrid plug-in vehicles

- Adjust the use of ethanol in place of petroleum

- Build HTGRs to assist in converting natural gas to diesel and gasoline

- Build HTGRs to assist in converting coal to diesel and gasoline. 


\subsubsection{Energy Price Stability}

Crude oil and natural gas are traded on a global market, and the prices fluctuate with demand, supply, conflicts, wars, and speculation. Increased conservation efforts and shifts to alternative technologies (e.g., plug-in hybrid vehicles) can reduce the U.S. demand on this volatile global market and shifts to an energy supply (electricity) that can be domestically controlled. Domestic gasoline and diesel production further reduces the U.S. demand for foreign imports and supplies the demand with a fully amortized product at a more predictable price.

Energy price stability can be quantified and valued using the same methods and equations employed to calculate call option prices in financial markets. The Black-Scholes option pricing model used extensively in today's financial markets was used in the 2050 SIM to calculate the value of "call options." Through a relationship known as put/call parity, the value of "put options" can also be calculated. The Black-Scholes model is developed using partial differential equations. Empirically, the model has been fairly justified, although some empirical failures have been noted. ${ }^{17}$

The call option prices developed in the 2050 SIM depict the value of purchasing crude oil or natural gas at a known price and at a certain time in the future. Just like investors are willing to pay a premium to buy a commodity for a known price at some time in the future, there is value (premium) in stable crude oil and natural gas pricing at some time in the future. The 2050 SIM uses the Black-Scholes model to calculate this value for crude oil and natural gas.

\subsubsection{Jobs Creation}

The creation of permanent U.S.-based engineering, manufacturing, and construction jobs while reducing the flow of capital offshore should remain a strategic U.S. priority. The number of jobs is estimated by year for the given energy strategy by calculating the job breakdown into the following seven areas: Engineering, Manufacturing, Construction, Operations, Decommissioning, Induced Operations, and Induced Construction. Each of these job areas is assigned a duration and a yearly number of associated jobs. The operation duration is equal to the plant life and starts at the year specified by the user as the start year of operation. The construction duration is the lead time minus 1 year and occurs in the years leading up to operations. Engineering and manufacturing start at the beginning of the lead time and last 1 to 3 years depending on plant data. Decommissioning starts at the end of operations and lasts 2 years. Induced construction and operations jobs occur during construction and operations, respectively. The jobs data come from four different sources. ${ }^{8,18,19,20}$ Projected job calculations resulting from the addition of HTGRs and other nuclear and renewable energy technologies is shown in Figure 11 (see Section 6). Projections beyond 2050 show job requirements for operation and maintenance only as no new construction is undertaken.

\subsection{Benefits Assumptions and Limitations}

The assumptions used for the benefits portion of the model are as follows:

5-1. Jobs data are broken down into the following areas: Engineering, Manufacturing, Construction, Operations, Decommissioning, Induced Construction, and Induced Operations

5-2. Each job duration is calculated based on the following rules:

a. Each new plant/process is assigned a lead time and a plant life.

b. The construction time period is assumed to be the lead time minus 1 year.

c. The operational time period is assumed to be equal to the plant life in years. 
d. Induced construction related jobs created are 50\% of Engineering, Manufacturing, and Construction jobs and are spread over the construction time period.

e. Induced operations related jobs created are $100 \%$ of Operations jobs and are spread over the operational time period (for Nuclear Power).

f. Decommissioning is assumed to have the same number of operational jobs for 2 years after operations end.

g. Engineering jobs start at the first year (operational date minus lead time) and last a default of 2 years, but can be changed for specific processes.

h. Manufacturing jobs start at the first year (operational date minus lead time) and last a default of 3 years, but can be changed for specific processes.

5-3. No new jobs are created for extending LWR licenses 20 years.

5-4. Emissions are based on EIA 2007 data $^{2}$ for total emissions for each energy sector and total energy used for each sector (see Table 2).

NOTE: As energy changes or is shifted from one sector to another (e.g., coal electric sectors changes from $51 \%$ to $40 \%$ ), the emissions for a specific year (for a specific sector) is calculated using the average release rate for that sector multiplied by the energy used that year for that sector.

5-5. The data source for CCS comes from Carbon Dioxide Capture from Existing Coal-Fired Power Plants. ${ }^{7}$

\section{USING THE MODEL}

The 2050 SIM was designed to provide a relatively simple but robust analytical tool for analyzing the U.S. energy supplies and demands. The tool is graphical user interface (GUI)-driven to facilitate easy navigation of the model through the Simulation Input Flow screen (see Figure 8). 


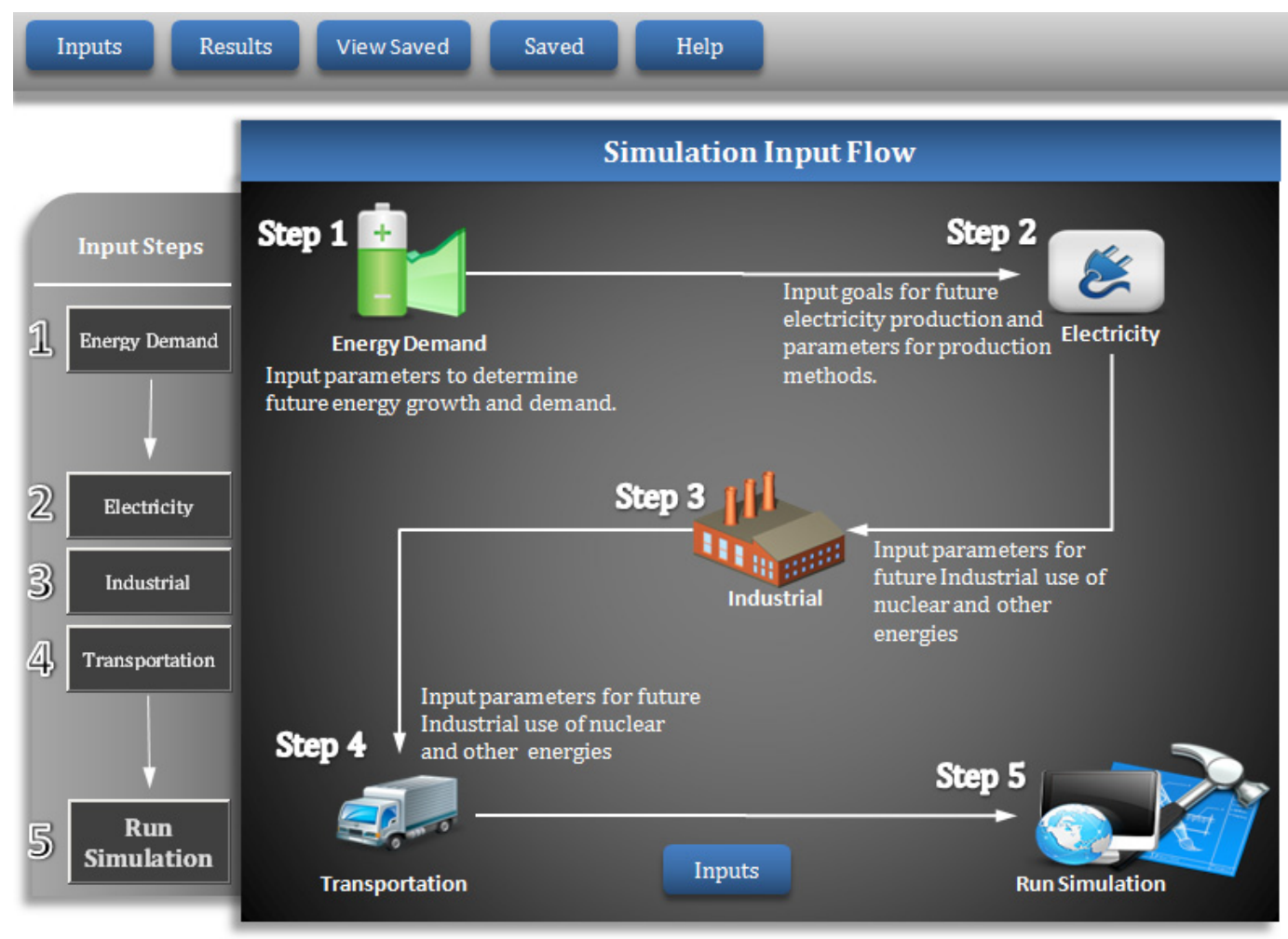

Figure 8. Simulation input flow [from 2050 SIM]

The model allows the user to select and test various scenarios and to visualize the results through the year 2050. The primary modules include sector specific supply and demand assessments for the transportation, industrial, residential, and commercial sectors. For example, the user projects future energy consumption and needs for the United States. As is seen in Figure 9, the user can select whether the analysis should be driven by projected GDP or by projected population growth. By inputting the percent change in GDP or population growth anticipated to occur in the future and the percent of energy that will be conserved or gained by increased energy efficiency, the user can visualize the projected impact of their chosen scenario on future energy consumption and demand. 


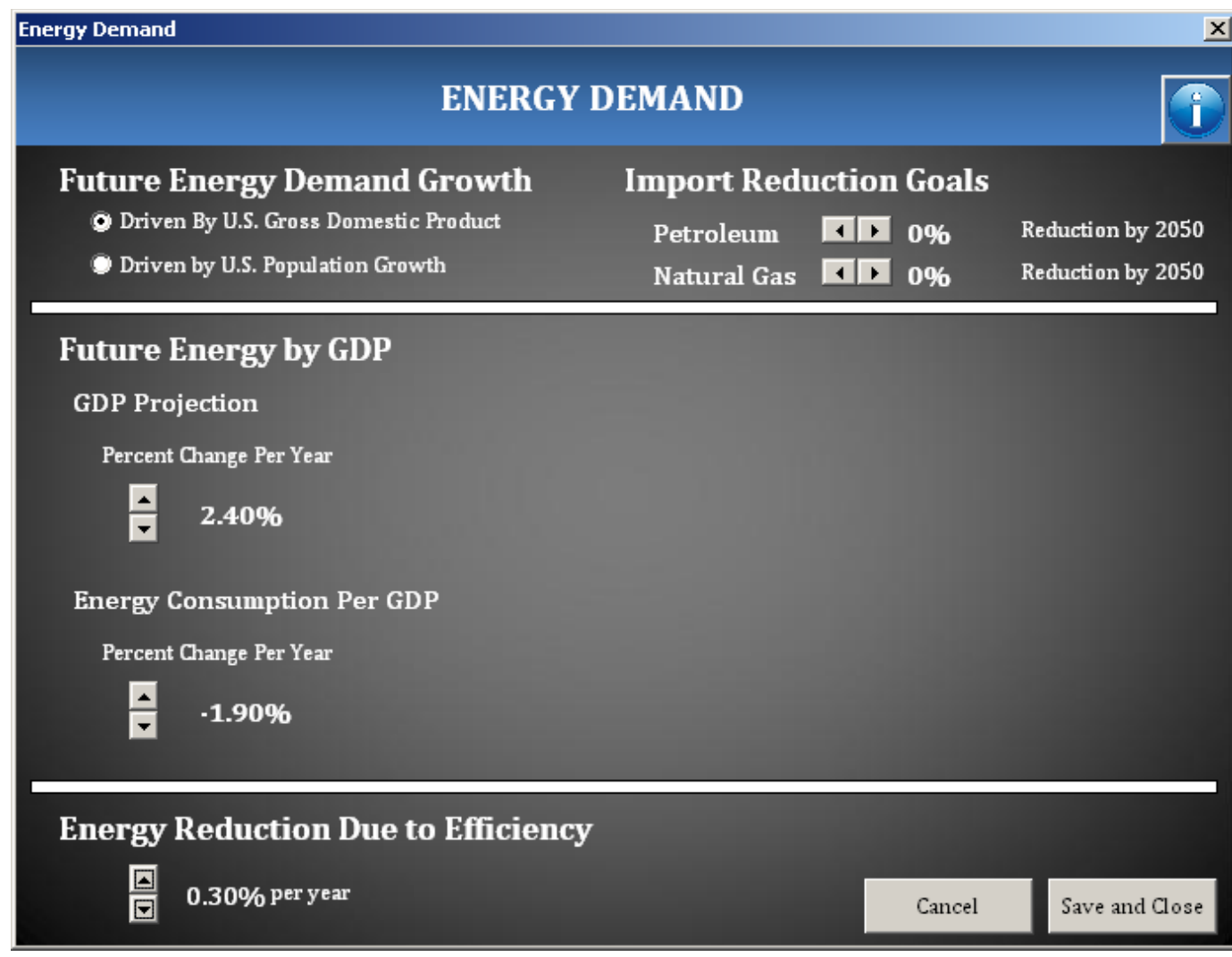

Figure 9. Future energy demand for the United States [from 2050 SIM]

Model outputs include: specific energy supply and demand information (e.g., oil and natural gas supply and demand) and the impacts of using various scenarios on energy imperatives, U.S. job creation, reduced U.S. dependency on foreign oil, improved energy prices stability, and reduced GHG emissions. For example, based on user inputs, 2050 SIM can create various scenarios relative to the number of HTGRs, wind farms, and solar plans that are deployed over time to display projected reductions in GHG emissions (see Figure 10) and projected numbers for the resulting engineering, manufacturing, and construction jobs (see Figure 11) through 2050. 


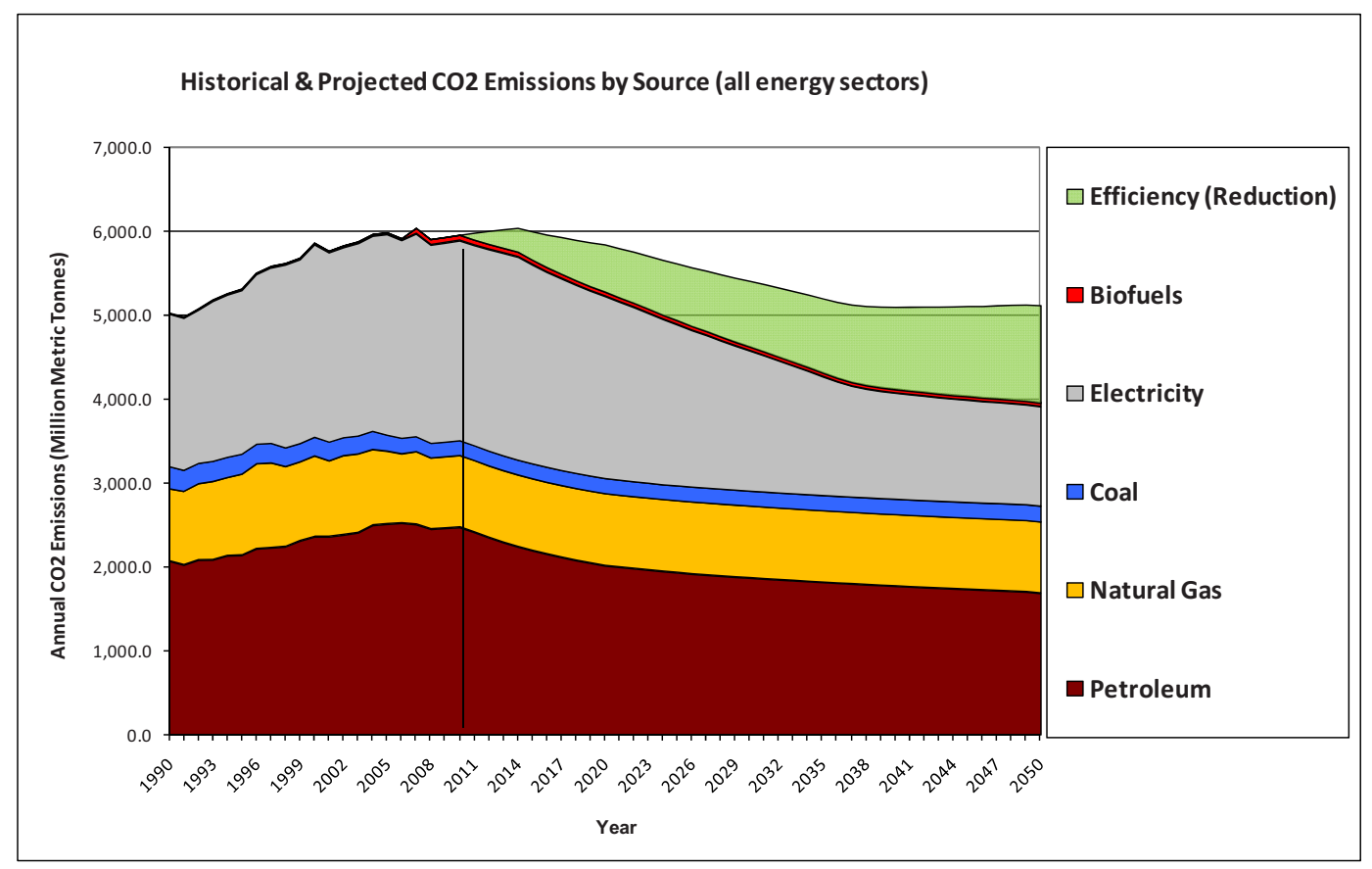

Figure 10. Historical and projected GHG emissions by source resulting from assumed efficiencies and additional HTGRs and other nuclear and renewable energy technologies [from 2050 SIM]

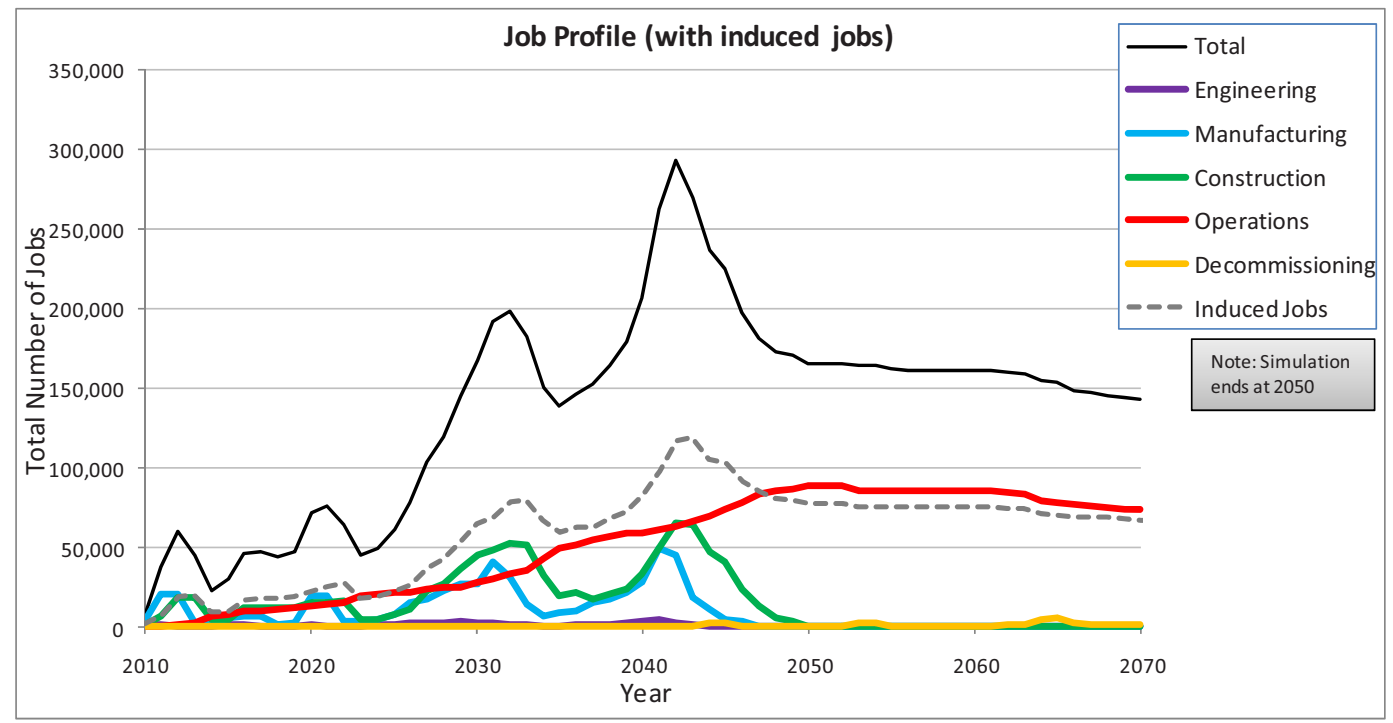

Figure 11. Job creation benefits in the United States [from 2050 SIM]

The model allows users to view results as graphical or tabular outputs and to save and print those outputs for later viewing or for use in reports.

\section{SUMMARY}

The 2050 SIM is a simple, robust tool that allows users to analyze domestic energy scenarios and determine for themselves the best mix of scenarios for overcoming the vulnerabilities demonstrated by the U.S. energy infrastructure while realizing the important benefits to stakeholders. The user can analyze the effects of overcoming U.S. energy infrastructure vulnerabilities with energy efficiency and conservations methods alone. The user can then add domestically produced transportation and power sources to witness 
the effect on vulnerabilities and the benefits realized. In addition, users can assess the potential benefits of nuclear power (particularly HTGRs) and renewables and the significant role each can play in transforming the U.S. energy infrastructure, reducing GHG emissions, stabilizing prices, achieving domestic energy independence, and creating jobs.

\section{REFERENCES}

1. Demick, L. E. Transforming the U.S. Energy Infrastructure. INL/EXT-09-17436. Idaho National Laboratory. July 2010.

2. EIA. Annual Energy Outlook 2010. DOE/EIA-0383(2010). Energy Information Administration. April 2010.

3. INL. Integration of High Temperature Gas-Cooled Reactors into Industrial Process Applications. INL/EXT-09-16942, Rev. 2. Idaho National Laboratory. May 2010.

4. THOMAS: Legislative Information from the Library of Congress. http://thomas.loc.gov

5. EIA. U.S. Nuclear Reactors. U.S. Energy Information Administration. http://www.eia.doe.gov/cneaf/nuclear/page/nuc reactors/reactsum.html

6. NETL. Cost and Performance Baseline for Fossil Energy Plants, Vol. 1. DOE/NETL-2007/1281. National Energy Technology Laboratory. May 2007.

7. NETL. Carbon Dioxide Capture from Existing Coal-Fired Power Plants. DOE/NETL401/110907. National Energy Technology Laboratory. November 2007

8. DOE. 2008 Geothermal Technologies Market Report. U.S. Department of Energy Geothermal Technology Program. July 2009.

9. INL. Nuclear-Integrated Coal and Gas to Liquids Production Analysis, Revision 1. TEV-672. Idaho National Laboratory. May 2010.

10. ORNL. Transportation Energy Data Book. ORNL-6984, Edition 28. U.S. Department of Energy. 2009.

11. INL. Nuclear-Integrated Methanol-to-Gasoline Production Analysis, Revision 1. TEV-677. Idaho National Laboratory. May 2010.

12. Haynes, W. M., Ed. Handbook of Chemistry and Physics. 91st Ed. West Palm Beach, FL: CRC Press. June 2010.

13. EIA. Electricity Generating Capacity. U.S. Energy Information Administration. http://www.eia.doe.gov/cneaf/electricity/page/capacity/capacity.html

14. Szklo, Alexandre, and Roberto Schaeffer. "Fuel Specification, Energy Consumption and CO2 Emission in Oil Refineries." Energy, Volume 32: Issue 7. July 2007.

15. Greenhouse Gases. Wikipedia. Last modified on September 22, 2010. http://en.wikipedia.org/wiki/Greenhouse_gases

16. EIA. Alternatives to Traditional Transportation Fuels: An Overview. Volume 2. DOE/EIA0585/O. Energy Information Administration. 1994

17. Devine, B. Energy Price Stability. TEV-1061. Idaho National Laboratory. September 2010.

18. URS. NGNP-HTGR Assisted Conventional Processes Jobs Creation and Energy Security Report. URS Corporation, 2010. 
19. Plum, M. M. (martin.plum@inl.gov). "Labor Estimates: Labor Demand Analysis of a StandAlone HTGR Electric Power Plant.” Email to John Collins (john.collins@inl.gov). August 11, 2010 .

20. NEI. New Nuclear Plants: An Engine for Job Creation, Economic Growth. Nuclear Energy Institute. January 2009. 